US Army Corps

of Engineers ${ }_{\circledast}$

Engineer Research and

Development Center

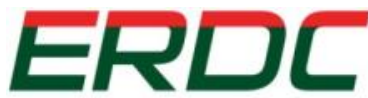

INNOVATIVE SOLUTIONS

for a safer, better world

\title{
Multiscale Assessment of Listed and At-Risk Species' Climate Change Vulnerabilities
}

Matthew G. Hohmann and Wade A. Wall

July 2017

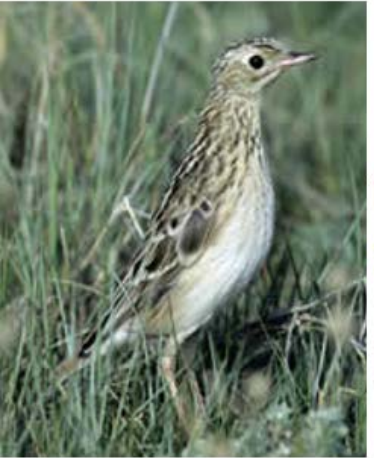

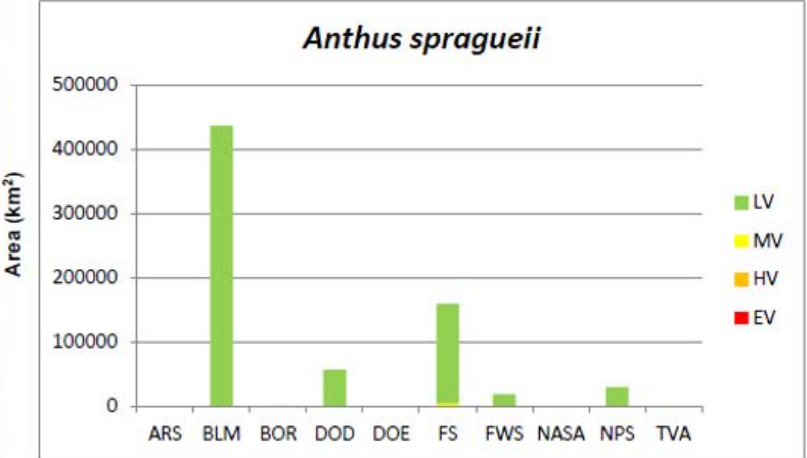

Federal Agency
Federal land area within the range of Anthus spragueii (Sprague's pipet) by agency and vulnerability categories

Federal land area within the range of Zapus hudsonius luteus (New Mexican jumping mouse) by agency and vulnerability categories.

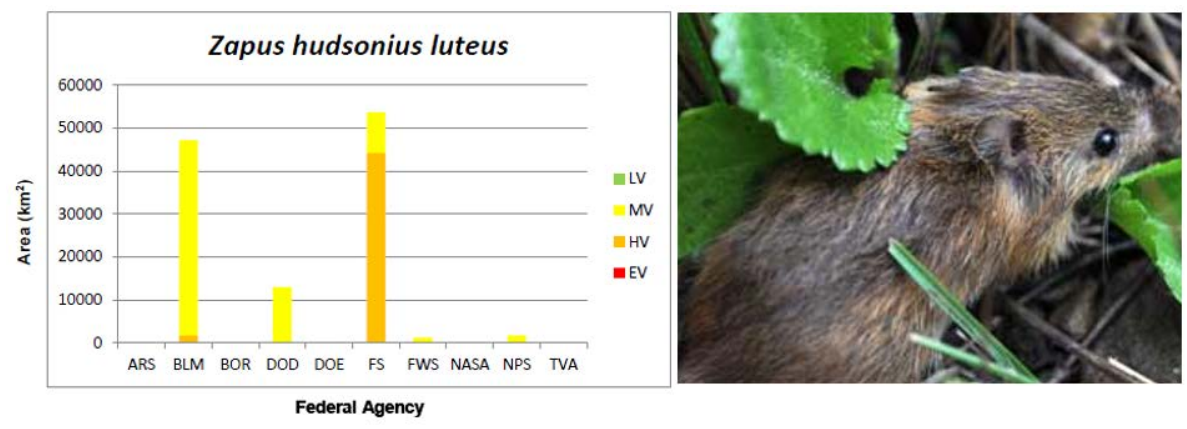


The U.S. Army Engineer Research and Development Center (ERDC) solves the nation's toughest engineering and environmental challenges. ERDC develops innovative solutions in civil and military engineering, geospatial sciences, water resources, and environmental sciences for the Army, the Department of Defense, civilian agencies, and our nation's public good. Find out more at www.erdc.usace.army.mil.

To search for other technical reports published by ERDC, visit the ERDC online library at http://acwc.sdp.sirsi.net/client/default. 


\section{Multiscale Assessment of Listed and At-Risk Species' Climate Change Vulnerabilities}

Matthew G. Hohmann and Wade A. Wall

U.S. Army Engineer Research and Development Center (ERDC)

Construction Engineering Research Laboratory (CERL)

2902 Newmark Dr.

Champaign, IL 61826

Final Report

Approved for public release; distribution is unlimited.

Prepared for Assistant Secretary of the Army for Acquisition, Logistics, and Technology, ASA(ALT)

Under Work Unit F94KF0, "Maneuver Area Capacity" 


\section{Abstract}

Climate change is of concern to the U.S. Department of Defense because climate change-driven increases in the number of species Federally listed under the U.S. Endangered Species Act (ESA) and stress to listed species can lead to additional requirements and potential restrictions on training land use. A first step in guiding management strategies to promote climate change adaptation is to assess species' vulnerabilities. However, vulnerability assessments conducted at a single scale or for arbitrary regions offer limited information to guide management decisions. This work developed and demonstrated an approach for multiscale species vulnerability assessments that integrates weighted estimates of range-wide and local vulnerability, and vulnerability on Federal land, where species' occurrence often influences ESA listing decisions. The approach was applied to 16 plant and animal species on five regionally representative Army installations. The assessments were used to rank species based on their occurrence on multiple installations across the Army and to rank the five study installations based on aggregate species' vulnerabilities. This approach is suitable for integrating climate change considerations into installation Integrated Natural $\mathrm{Re}$ source Management Plans, for evaluating whether climate change-driven impacts to listed species will affect installation resilience, and for identifying potential conservation partners among Federal land managers.

DISCLAIMER: The contents of this report are not to be used for advertising, publication, or promotional purposes. Citation of trade names does not constitute an official endorsement or approval of the use of such commercial products. All product names and trademarks cited are the property of their respective owners. The findings of this report are not to be construed as an official Department of the Army position unless so designated by other authorized documents.

DESTROY THIS REPORT WHEN NO LONGER NEEDED. DO NOT RETURN IT TO THE ORIGINATOR. 


\section{Contents}

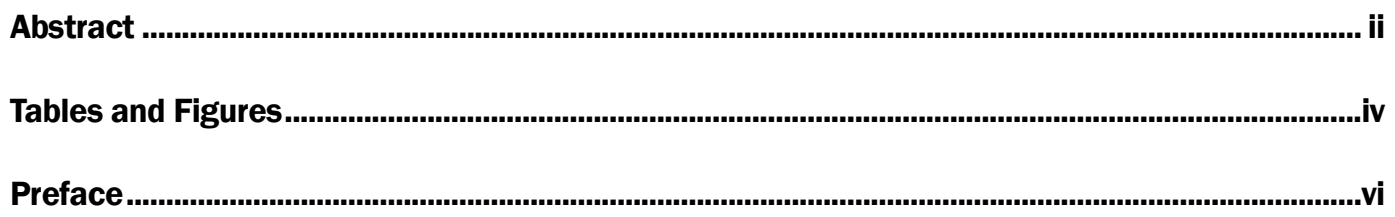

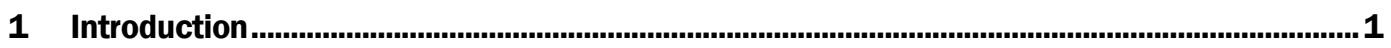

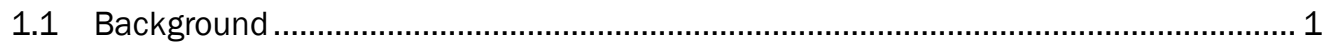

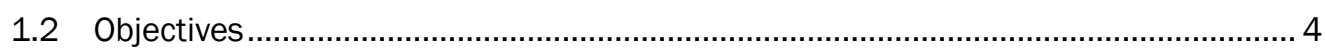

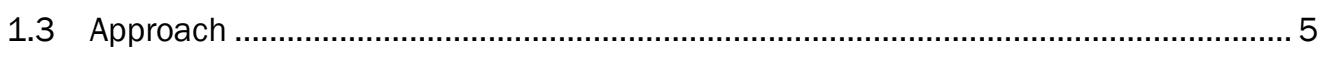

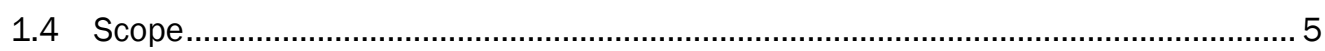

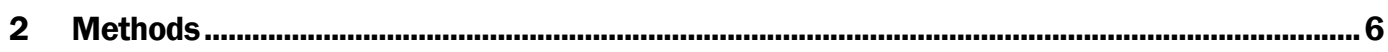

2.1 Climate change vulnerability assessments.......................................................... 7

2.2 Calculating species' climate change vulnerability at range-wide and local

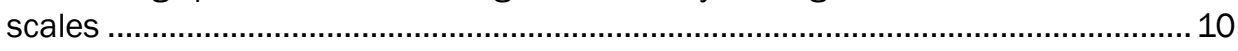

2.3 Assessing species' climate change vulnerabilities across Federal lands and

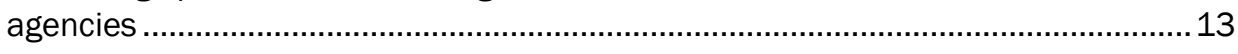

2.4 A multiscale index of species vulnerability ......................................................... 14

2.5 Assessing species climate change vulnerabilities across the Army ........................15

2.6 Ranking installations based on emerging climate change vulnerabilities ................ 16

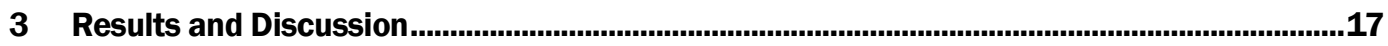

3.1 Species' range-wide climate change vulnerabilities ............................................... 17

3.2 Species' climate change vulnerabilities across Federal agency lands.....................18

3.3 Species' climate change vulnerabilities on installations..........................................25

3.4 Multiscale index of species' climate change vulnerabilities ....................................26

3.5 Army-wide exposure to potential impacts of species' climate change vulnerabilities ......................................................................................................... 27

3.6 Installation exposure to potential impacts of multiple species' climate

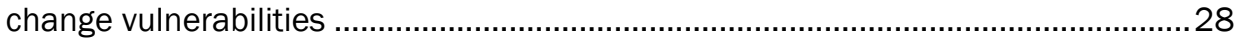

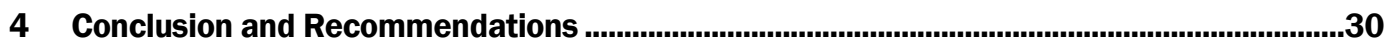

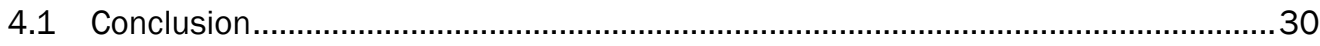

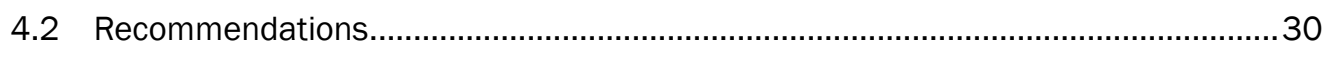

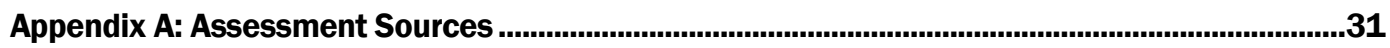

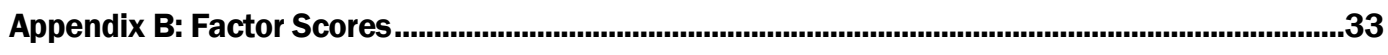

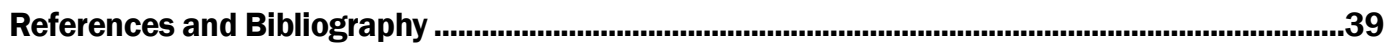

Acronyms and Abbreviations ...............................................................................................4

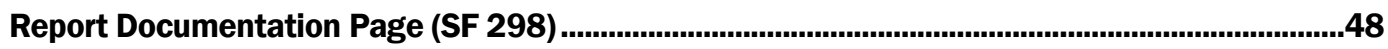




\section{Tables and Figures}

\section{Tables}

1 Species' scientific names, common names and taxonomic groups for the five regionally distinct installations

2 Factors assessed by the NatureServe Climate Change Vulnerability Index tool (Young et al. 2015)

3 Anthropogenic barriers categories and the binned percentages of species' rangewide and local scale (i.e., $50 \mathrm{~km}$ buffers of Federal lands) assessment areas represented by developed, pasture/hay and cultivated crop cover types within the 2011 National Land Cover Dataset that were used to characterize them.

4 Multipliers used to characterize the relative reduction in the suitability or carrying capacity of Federal lands occurring within species' ranges due to climate change vulnerability. The percent area of each Federal land parcel within species' ranges was subjected to the multiplier associated with the NatureServe Climate Change Vulnerability Categories

5 Ranked list of species' range-wide climate change variability, based on sequential evaluation of index of vulnerability on Federal lands, and Federal lands area within species' ranges.

6 Ranking of species on installations by local (installation-specific) climate change vulnerabilities

7 Ranking of species on installations by local (installation-specific) climate change

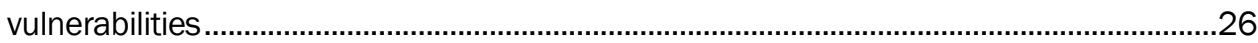

8 Ranked list of species based on climate change vulnerabilities across Army.....................28

9 Ranked list of study installations based on aggregate index of species' climate change vulnerabilities

\section{Figures}

1 Federal land area $\left(\mathrm{km}^{2}\right)$ within the range of Amorpha georgiana (Georgia leadplant) by agency and vulnerability categories.

2 Federal land area $\left(\mathrm{km}^{2}\right)$ within the range of Anthus spragueii (Sprague's pipet) by agency and vulnerability categories.

3 Federal land area $\left(\mathrm{km}^{2}\right)$ within the range of Coccyzus americanus occidentalis (Western yellow-billed cuckoo) by agency and vulnerability categories

4 Federal land area $\left(\mathrm{km}^{2}\right)$ within the range of Eremophila alpestris strigata (streaked horned lark) by agency and vulnerability categories

5 Federal land area $\left(\mathrm{km}^{2}\right)$ within the range of Euphydryas editha taylori (Taylor's checkerspot) by agency and vulnerability categories

6 Federal land area $\left(\mathrm{km}^{2}\right)$ within the range of Isoetes hyemalis (winter quillwort) by agency and vulnerability categories

7 Federal land area $\left(\mathrm{km}^{2}\right)$ within the range of Lindera subcoriacea (bog spicebush) by agency and vulnerability categories.

8 Federal land area $\left(\mathrm{km}^{2}\right)$ within the range of Lobelia boykinii (Boykin's lobelia) by agency and vulnerability categories. 
9 Federal land area $\left(\mathrm{km}^{2}\right)$ within the range of Nuphar lutea sagittifolia (Cape Fear spatterdock) by agency and vulnerability categories...........................................................22

10 Federal land area $\left(\mathrm{km}^{2}\right)$ within the range of Myotis septentrionalis (northern longeared bat) by agency and vulnerability categories .23

11 Federal land area $\left(\mathrm{km}^{2}\right)$ within the range of Rana pretiosa (Oregon spotted frog) by agency and vulnerability categories............................................................................23

12 Federal land area $\left(\mathrm{km}^{2}\right)$ within the range of Thomomys mazama glacialis (Roy Prairie pocket gopher) by agency and vulnerability categories

13 Federal land area $\left(\mathrm{km}^{2}\right)$ within the range of Thomomys mazama pugetensis (Olympia pocket gopher) by agency and vulnerability categories........................................24

14 Federal land area $\left(\mathrm{km}^{2}\right)$ within the range of Thomomys mazama tumuli (Tenino pocket gopher) by agency and vulnerability categories

15 Federal land area $\left(\mathrm{km}^{2}\right)$ within the range of Zapus hudsonius luteus (New Mexican jumping mouse) by agency and vulnerability categories 


\section{Preface}

This study was conducted for Office of the Assistant Secretary of the Army for Acquisition, Logistics, and Technology, ASA(ALT) under Program Element 622720A896, "Army Environmental Quality Technology"; Work Unit F94KF0, "Maneuver Area Capacity." The technical monitor was Steve Sekscienski, OACSIM-ISE.

This work was conducted by the Ecological Processes Branch (CNN), Installations Division (CN), Construction Engineering Research Laboratory (CERL), Engineer Research and Development Center (ERDC). At the time of publication, Dr. Chris Rewerts was Chief, CEERD-CNN, and Michelle J . Hanson was Chief, CEERD-CN. The associated Technical Director was Alan Anderson, CEERD-CZT. The Deputy Director of ERDC-CERL was Dr. Kirankumar Topudurti and the Director was Dr. Ilker Adiguzel.

COL Bryan S. Green was Commander of ERDC, and Dr. David W. Pittman was the Director. 


\section{Introduction}

\subsection{Background}

Federal land management agencies must manage numerous threatened, endangered, and at-risk species, i.e., taxa assessed by NatureServe as critically imperiled (G1/T1) or imperiled (G2/T2) (NatureServe 2011), a challenge that will be exacerbated by climate change (Urban 2015). The magnitude of the added challenge posed by climate change to management will not only be determined by species' vulnerability within the portions of their ranges encompassed by agencies' properties, but also by those species' range-wide or regional vulnerability, because the prospects for species' recovery and the strategies available to achieve that recovery are a combination of both local and range-wide factors.

For example, climate change-driven loss of habitat in a large portion of a sensitive species' range will likely constrain certain adaptation strategies and demand others. To date, there is a trend among public land managers to use single scale climate change vulnerability assessments. These assessments focus primarily on single facilities, regions, or jurisdictional boundaries that individually may not have inherent biological meaning for species conservation (e.g., Byers and Norris 2011), and that therefore offer limited insight about what adaptation strategies might be most appropriate. Informed, best-science, climate change adaptation planning that embraces interagency collaboration can only be achieved with information about species' vulnerability across multiple scales.

Climate change vulnerability is generally described as a function of sensitivity, exposure, and adaptive capacity (Schneider et al. 2007, Williams et al. 2008). Sensitivity to climate change is characterized by the degree to which a species is affected by climate variables (e.g., drought, extreme temperatures) and is primarily determined by intrinsic factors such as species' physiology, genetics, life history traits, and dependence on specific habitats or other species. Exposure is characterized by the magnitude and rate of climate change a species is expected to experience. Different regions of the United States are projected to vary in their direct and indirect exposure to climate change, such that large-ranged and migratory species will likely be subject to variable climate change exposure. Adaptive capacity refers to the ability of a species to persist where it currently occurs, or 
to migrate to suitable locations. Knowing the consequences of spatial variability in exposure and adaptive capacity on species' climate change vulnerability can inform adaptation strategy. For example, even though a specific agency's properties may be in a poor position to meaningfully contribute to the long-term conservation of some species due to overwhelming climate change exposure, they may still lead regional or rangewide efforts for other species.

The U.S. Department of Defense (DoD) is the fifth largest land management agency in the United States; it manages over 12 million hectares of land on more than 425 military installations (Stein Scott, and Benton 2008). Although this represents less than $5 \%$ of the land managed by the four larger agencies combined, 23\% of all U.S. Endangered Species Act (ESA) status (endangered, threatened, candidate, or proposed species) and $15 \%$ of all atrisk species under the stewardship of these five agencies occur on DoD lands (Stein Scott, and Benton 2008). Additionally, more of these DoD ESA status (270; ACSIM 2010) and at-risk species (220; NatureServe 2011) occur on Army lands than on all other DoD services combined. Given the recent U.S. Fish and Wildlife Service (USFWS) lawsuit settlement requiring review of 757 species proposed for listing under the ESA by 2018 (Endangered Species Act Section 4 Deadline Litigation, case number 2165, U.S. District Court for the District of Columbia), a substantive number (ca. 230) of additional listed species are anticipated to occur on or near Army and Army National Guard installations (Sperry, Wall, and Hohmann 2016). The currently large and increasing Army conservation responsibility related to Federally listed and at-risk species highlights the importance of proactively conducting climate change vulnerability assessments. Assessments of species' vulnerability can help prioritize investment of limited conservation funding and identify potential conservation partnership opportunities to effectively manage species in the face of climate change.

Executive Order (EO) 13514, Federal Leadership in Environmental, Energy and Economic Performance (White House 2009) required Federal agencies to address climate change risks and vulnerabilities in short- and long-term planning. The DoD first acknowledged the potential impacts of climate change on its facilities, infrastructure, military capabilities, and training and testing activities within the 2010 Quadrennial Defense Review (DoD 2010). Subsequently, the DoD issued Department of Defense Instruction (DODI) 4715.03 (DoD 2011) pertaining to its Natural Resources Conservation Program, which requires DoD installations to: 
(1) address climate change in their Integrated Natural Resources Management Plans (INRMPs), (2) use the best available science to assess potential climate change impacts, and (3) use adaptive strategies to address those impacts. In 2013, this Instruction was followed by Department of Defense Manual (DoDM) 4715.03, the Integrated Natural Resources Management Plan Implementation Manual (DoD 2013), which outlined procedures for preparing, reviewing, updating, and implementing INRMPs in accordance with Department of Defense Instruction (DODI) 4715.03.

In response to EO 13514, DoD also developed a Climate Change Adaptation Roadmap (CCAR) in 2012 (DoD 2012). The CCAR fulfilled a requirement to include an adaptation planning document as an appendix to the Department's annual Strategic Sustainability Performance Plan. The CCAR established broad climate change adaptation goals to:

1. Develop a coordinating committee to address climate change, (2) use the best available science to inform decisions

2. Integrate climate change information into existing processes

3. Encourage partnerships with other agencies (DoD 2012).

Given that impacts to DoD are expected to vary by region, assessing vulnerability to climate change is a large component of the CCAR framework. The CCAR included a detailed table highlighting specific climate change phenomena, potential impacts, and potential mission vulnerabilities. Among the listed potential impacts are stress to protected species and an increase in the number of species at risk.

In 2013, EO 13653, Preparing the United States for the Impacts of Climate Change (White House 2013), charged DoD and other Federal agencies to:

complete an inventory and assessment of proposed and completed changes to their land- and water-related policies, programs, and regulations necessary to make the Nation's watersheds, natural resources, and ecosystems, and the communities and economies that depend on them, more resilient in the face of a changing climate.

This executive order also charged DoD and other Federal agencies to "develop and provide authoritative, easily accessible, usable, and timely data, 
information, and decision-support tools on climate preparedness and resilience." EO 13653 also mandated regular updates to and implementation of the agency adaptation plans required under EO 13514.

In 2014, DoD updated its CCAR in response to requirements set out in EO 13653 (DoD 2014a). In alignment with EO 13653, the updated CCAR established three broad adaptation goals: (1) to identify and assess the effect of climate change on the Department, (2) to integrate climate change considerations across the Department and manage associated risks, (3) to collaborate with internal and external stakeholders on climate change challenges. Each of these goals was evaluated in relation to DoD's plans and operations, training and testing, built and natural infrastructure, and acquisition and supply chain. Additionally, a summary of the potential impacts to DoD's mission was provided within Annex 2 of the 2014 CCAR. Similar to the 2012 roadmap, the 2014 CCAR explicitly identified concerns about climate change-related stress to currently listed threatened and endangered species both on and adjacent to DoD installations. Increased numbers of listed and at-risk species and associated management requirements and challenges were also identified as concerns.

Although these mandates and requirements for the DoD and the Army to address climate change are in place, specific approaches that might be adopted to address assessment, monitoring, and adaptation strategies are still evolving (GAO 2009, 2014). Vulnerability assessments are an important first step in ensuring future conservation successes for listed and at-risk species. Multiscale climate change assessments are critical given the importance of range-wide and Federal lands vulnerabilities in informing installation-scale prioritization of management efforts, and in developing viable adaptation strategies. However, this information is not widely available to installation, regional, or Headquarters decision makers. This work attempts to fill that information gap by demonstrating an approach to assess species' multiscale climate change vulnerabilities.

\subsection{Objectives}

The objectives of this effort were to: (1) demonstrate an approach for assessing species' multiscale climate change vulnerabilities, (2) conduct multiscale climate change vulnerability assessments for species that have been either Federally listed as threatened or endangered since 2012, or are currently under review for listing and known to occur on/ or near five regionally distinct Army installations, and (3) use the estimated vulnerabilities to 
rank species based on their occurrence on multiple installations across the Army and to rank the five study installations based on the aggregate vulnerabilities of species.

\subsection{Approach}

The objectives of this work were accomplished in five primary tasks:

1. Identification of the target species for each of the five installations

2. Assessment of the species' range-wide climate change vulnerabilities

3. Assessment of the species' local climate change vulnerabilities on Federal lands including the five regional installations

4. Integration of local and range-wide vulnerabilities in a multiscale index

5. Comparison of the species' climate change vulnerabilities across the different scales and locations.

\subsection{Scope}

The climate change vulnerability assessments within this effort focused on species that have been either Federally listed as threatened or endangered since 2012, or are currently under review for listing and known to occur on or near five regionally distinct Continental United States (CONUS) installations. Species already listed under the Endangered Species Act before the 2011 USFWS lawsuit settlement, DoDI 2011, and EO 2012 were determined to likely already have been, or to already be in the process of being evaluated for climate change vulnerabilities within installation Threatened and Endangered Species Management Plans and/ or revisions of INRMPs. Assessments were made using climate change projection data for the year 2050. 


\section{Methods}

The species examined in this effort include those identified in Sperry, Wall, and Hohmann (2016), and exclude any that could not be confirmed to occur on the five study installations by a review of INRMPs. This study conducted a national level assessment of the risk to Army training by species petitioned or under review for Federal listing as a result of a USFWS 2011 lawsuit settlement. Table 1 lists species' scientific names, common names, and taxonomic groups for the five regionally distinct installations.

Table 1. Species' scientific names, common names and taxonomic groups for the five regionally distinct installations.

\begin{tabular}{|c|c|c|c|}
\hline Installation & Species & Common Name & Taxonomic Group \\
\hline \multicolumn{4}{|l|}{ Fort Bliss } \\
\hline & Zapus hudsonius luteus & New Mexican jumping mouse & mammal \\
\hline & $\begin{array}{l}\text { Coccyzus americanus } \\
\text { occidentalis }\end{array}$ & Western yellow-billed cuckoo & bird \\
\hline & Anthus spragueii & Sprague's pipet & bird \\
\hline \multicolumn{4}{|l|}{ Fort Bragg } \\
\hline & Amorpha georgiana & Georgia leadplant & plant \\
\hline & Lindera subcoriacea & bog spicebush & plant \\
\hline & Isoetes hyemalis & winter quillwort & plant \\
\hline & Myotis septentrionalis & northern long-eared bat & mammal \\
\hline & Lobelia boykinii & Boykin's lobelia & plant \\
\hline & Nuphar lutea sagittifolia & Cape Fear spatterdock & plant \\
\hline \multicolumn{4}{|l|}{ Fort Drum } \\
\hline & Myotis septentrionalis & northern long-eared bat & mammal \\
\hline \multicolumn{4}{|c|}{ Joint Base Lewis-McCord } \\
\hline & Rana pretiosa & Oregon spotted frog & amphibian \\
\hline & $\begin{array}{l}\text { Thomomys mazama } \\
\text { pugetensis }\end{array}$ & Olympia pocket gopher & mammal \\
\hline & Thomomys mazama tumuli & Tenino pocket gopher & mammal \\
\hline & Thomomys mazama yelmensis & Yelm pocket gopher & mammal \\
\hline & Thomomys mazama glacialis & Roy Prairie pocket gopher & mammal \\
\hline & Eremophila alpestris strigata & streaked horned lark & bird \\
\hline & Euphydryas editha taylori & Edith's checkerspot & butterfly \\
\hline \multicolumn{4}{|l|}{ Fort Riley } \\
\hline & Myotis septentrionalis & northern long-eared bat & Mammal \\
\hline
\end{tabular}




\subsection{Climate change vulnerability assessments}

Multiple approaches for estimating species' and regional climate change vulnerabilities have been proposed and adopted. Two good examples include the U.S. Environmental Protection Agency's (USEPA's) National Center for Environmental Assessment framework (USEPA 2009); and NatureServe's Climate Change Vulnerability Index (NS CCVI) (Young, Dubois, and Rowland 2014; Young et al. 2015; Bagne, Friggens, and Finch 2011). This effort used the NS CCVI version 3.0 to assess local and rangewide vulnerabilities, and followed available guidelines except where noted below. The NS CCVI index places species into one of five vulnerability categories (extremely vulnerable, highly vulnerable, moderately vulnerable, less vulnerable, and insufficient evidence) for the specific geographical area assessed, through 2050 (Young et al. 2015). It uses information on 23 factors to characterize species' sensitivity, exposure, and capacity to adapt to climate change. Examples of these factors include exposure to sea-level change, phenological response to changing seasonal temperature or precipitation, and dispersal and movement capability. Table 2 lists and briefly describes these factors. Young et al. (2015) provide additional details and scoring guidelines for the factors.

The NS CCVI can be used to assess species' relative vulnerability, to identify the most important factors affecting vulnerability, to identify conservation priorities across specific areas (e.g., jurisdictional boundaries), and to promote coordination and consistency in adaptation planning and management (Young et al. 2015). It has also been used previously to assess the climate change vulnerability of species of concern on Army installations (Sperry and Hayden 2011). However, application of the index is somewhat constrained in regions outside the conterminous United States due to availability of consistent climate data and certain design features. The tool, which is programmed in a Microsoft ${ }^{\circledR}$ Excel ${ }^{\circledR}$ workbook, is freely available for download at www.natureserve.org/ccvi. Given the availability and thoroughness of the NS CCVI guidance documents, exhaustive details are avoided here except where methodological deviations occur.

By applying the NS CCVI across species' entire ranges and specifically to the portions of their ranges represented by installations and other Federal lands, and then by comparing values across species and locations, this effort sought to: (1) identify the relative threat that climate change likely poses for the future conservation of different species, (2) assess the chal- 


\section{lenges that climate change likely poses for installations' ability to posi- tively affect species' conservation, and (3) identify the conservation part- nering and adaptation strategies likely available.}

\section{Table 2. Factors assessed by the NatureServe Climate Change Vulnerability Index tool (Young} et al. 2015).

\begin{tabular}{|c|c|c|}
\hline Aspect of Vulnerability* & Factor & Description \\
\hline \multirow[t]{2}{*}{ A. Direct Exposure } & A1. Temperature Change & $\begin{array}{l}\text { Predicted change in annual temperature by } 2050 \text {, } \\
\text { calculated over the range of the species and for Federal } \\
\text { lands. }\end{array}$ \\
\hline & A2. Moisture Change & $\begin{array}{l}\text { Predicted net change in moisture based on the Hamon } \\
\text { AET:PET Moisture Metric, calculated over the range of } \\
\text { the species and for Federal lands. }\end{array}$ \\
\hline \multirow[t]{4}{*}{ B. Indirect Exposure } & B1. Sea-Level Rise & $\begin{array}{l}\text { Predicted increase in sea level and consequent influence } \\
\text { of storm surges calculated over the range of the species } \\
\text { and for Federal lands there. }\end{array}$ \\
\hline & B2A. Natural Barriers & $\begin{array}{l}\text { Topographic, geographical, and/or ecological features of } \\
\text { the landscape that may naturally restrict a species from } \\
\text { dispersing to new areas. }\end{array}$ \\
\hline & B2B. Anthropogenic Barriers & $\begin{array}{l}\text { Anthropogenically altered landscapes (e.g., urban or } \\
\text { agricultural areas) that may hinder the dispersal of a } \\
\text { species. }\end{array}$ \\
\hline & $\begin{array}{l}\text { B3. Land Use Changes from } \\
\text { Climate Change Mitigation }\end{array}$ & $\begin{array}{l}\text { Strategies designed to mitigate greenhouse gases (e.g., } \\
\text { large wind farms, biofuel production, solar arrays, carbon } \\
\text { offsets), or other threats. }\end{array}$ \\
\hline \multirow[t]{6}{*}{$\begin{array}{l}\text { C. Sensitivity and Adaptive } \\
\text { Capacity }\end{array}$} & C1. Dispersal/ Movement & $\begin{array}{l}\text { Known or predicted dispersal or movement capability of } \\
\text { species and ability to shift location as conditions change } \\
\text { due to climate change. Limited dispersal or movement } \\
\text { capability is expected to increase vulnerability. }\end{array}$ \\
\hline & C2ai. Historical Thermal Niche & $\begin{array}{l}\text { Mean seasonal temperature variation (difference } \\
\text { between the highest mean monthly maximum } \\
\text { temperature and lowest mean monthly minimum } \\
\text { temperature from 1951-2006) calculated over the range } \\
\text { of the species and Federal lands. Species exposed to low } \\
\text { seasonal temperature variation are expected to be more } \\
\text { vulnerable than species exposed to high seasonal } \\
\text { temperature variation. }\end{array}$ \\
\hline & $\begin{array}{l}\text { C2aii. Physiological Thermal } \\
\text { Niche }\end{array}$ & $\begin{array}{l}\text { Species' predicted sensitivity due to specific } \\
\text { requirements for relatively cool temperature regimes. }\end{array}$ \\
\hline & $\begin{array}{l}\text { C2bi. Historical Hydrological } \\
\text { Niche }\end{array}$ & $\begin{array}{l}\text { Mean annual precipitation variation (difference between } \\
\text { the maximum and minimum from 1951-2006) } \\
\text { calculated over the range of the species and for Federal } \\
\text { lands. }\end{array}$ \\
\hline & $\begin{array}{l}\text { C2bii. Physiological Hydrological } \\
\text { Niche }\end{array}$ & $\begin{array}{l}\text { Species' predicted sensitivity due to specific } \\
\text { requirements for narrow precipitation/hydrologic } \\
\text { regimes. }\end{array}$ \\
\hline & C2c. Disturbance & $\begin{array}{l}\text { Species' dependence on specific disturbance regimes } \\
\text { (e.g., fire or flooding likely to be impacted by climate } \\
\text { change). Dependence on specific disturbance regimes is } \\
\text { expected to increase vulnerability. }\end{array}$ \\
\hline
\end{tabular}

\footnotetext{
* Note that the numbering hierarchy in this table follows that used within the tool.
} 


\begin{tabular}{|c|c|c|}
\hline Aspect of Vulnerability* & Factor & Description \\
\hline & C2d. Ice/Snow & $\begin{array}{l}\text { Species' dependence on habitats associated with ice, ice } \\
\text { edge, or snow cover. Dependence on these habitats is } \\
\text { expected to increase vulnerability. }\end{array}$ \\
\hline & C3. Rarity of Physical Habitat & $\begin{array}{l}\text { Species' dependence on uncommon geological features } \\
\text { or derivatives (e.g., specific substrates, soils, or physical } \\
\text { features such as caves, cliffs, or sand dunes). }\end{array}$ \\
\hline & $\begin{array}{l}\text { C4a. Dependence on Other } \\
\text { Species for Habitat }\end{array}$ & $\begin{array}{l}\text { Specificity of species' dependence on habitat generated } \\
\text { by other species (e.g., burrows, cavities). }\end{array}$ \\
\hline & c4b. Diet Specialization & $\begin{array}{l}\text { Specificity of species' diets. Only applicable to animals. } \\
\text { Dietary specialists are more likely to be negatively } \\
\text { affected by climate change than species that consume } \\
\text { diverse food types (e.g., omnivores). }\end{array}$ \\
\hline & C4c. Pollinators Specialization & $\begin{array}{l}\text { Specificity of species' reliance on other species for } \\
\text { pollination. Only applicable to plants. Pollinator } \\
\text { specialists are more likely to be negatively affected by } \\
\text { climate change than species with multiple pollinators. }\end{array}$ \\
\hline \multirow[t]{8}{*}{$\begin{array}{l}\text { Sensitivity and Adaptive } \\
\text { Capacity }\end{array}$} & $\begin{array}{l}\text { C4d. Dependence on Other } \\
\text { Species for Dispersal }\end{array}$ & $\begin{array}{l}\text { Specificity of species' reliance on other species for } \\
\text { propagule dispersal. Applicable to both plants and } \\
\text { animals. Dispersal specialists are more likely to be } \\
\text { negatively affected by climate change than are species } \\
\text { with many dispersal agents or species that are not reliant } \\
\text { on other species for dispersal (e.g., most animals). }\end{array}$ \\
\hline & $\begin{array}{l}\text { C4e. Sensitivity to Pathogens or } \\
\text { Natural Enemies }\end{array}$ & $\begin{array}{l}\text { Anticipated change in impact or abundance of pathogens } \\
\text { and natural enemies (e.g., predators, parasitoids, or } \\
\text { herbivores) due to climate change. }\end{array}$ \\
\hline & $\begin{array}{l}\text { C4f. Sensitivity to Competition } \\
\text { From Native or Non-native } \\
\text { Species }\end{array}$ & $\begin{array}{l}\text { Anticipated change in impact or abundance of native or } \\
\text { non-native competitors due to climate change. }\end{array}$ \\
\hline & $\begin{array}{l}\text { C4g. Dependence on Any Other } \\
\text { Species Interaction }\end{array}$ & $\begin{array}{l}\text { Specificity of species' reliance on other species for } \\
\text { interactions (e.g., mutualism, parasitism, commensalism, } \\
\text { or predator-prey relationship) not captured by the } \\
\text { preceding four factors. }\end{array}$ \\
\hline & $\begin{array}{l}\text { C5a. Documented Genetic } \\
\text { Variation }\end{array}$ & $\begin{array}{l}\text { Relative amount of genetic variation reported for species } \\
\text { compared to findings on related taxa using similar } \\
\text { techniques. Low genetic variation is presumed to be a } \\
\text { constraint on adaptation. }\end{array}$ \\
\hline & C5b. Past Genetic Bottleneck & $\begin{array}{l}\text { Used only if genetic variation is unknown. Evidence of a } \\
\text { past genetic bottleneck suggests some potential loss of } \\
\text { genetic variation and increased vulnerability. }\end{array}$ \\
\hline & C5c. Reproductive System & $\begin{array}{l}\text { Proxy evaluated only for plants and when information } \\
\text { about species' genetic variation and past genetic } \\
\text { bottlenecks is unavailable. }\end{array}$ \\
\hline & $\begin{array}{l}\text { C6. Documented Phenological } \\
\text { Response }\end{array}$ & $\begin{array}{l}\text { Relative change in phenological variables (e.g., flowering } \\
\text { or migration times) in response to changes in climate. A } \\
\text { lack of change in phenological variables is presumed to } \\
\text { increase vulnerability. Species restricted to asexual } \\
\text { reproduction are expected to be more vulnerable than } \\
\text { species with either obligate outcrossing or mixed mating } \\
\text { (selfing and outcrossing) systems when no disruptions to } \\
\text { gene flow (e.g., range disjunctions) or outbreeding } \\
\text { depression are known. }\end{array}$ \\
\hline $\begin{array}{l}\text { D. Documented or Modeled } \\
\text { Response }\end{array}$ & $\begin{array}{l}\text { D1. Documented Response to } \\
\text { Recent Climate Change }\end{array}$ & $\begin{array}{l}\text { Degree to which a species is known to have responded } \\
\text { to climate change over the past } 10 \text { years or three } \\
\text { generations, whichever is longer. }\end{array}$ \\
\hline
\end{tabular}




\begin{tabular}{|l|l|l|}
\hline Aspect of Vulnerability* & Factor & Description \\
\hline & $\begin{array}{l}\text { D2. Modeled Future (2050) } \\
\text { Change in Range or Population } \\
\text { Size }\end{array}$ & $\begin{array}{l}\text { Predicted future change in species' range size or } \\
\text { abundance (expressed as a percentage) as a result of } \\
\text { climate change. }\end{array}$ \\
\cline { 2 - 3 } & $\begin{array}{l}\text { D3. Overlap of Modeled Future } \\
\text { Range and Current Range }\end{array}$ & $\begin{array}{l}\text { Percent of species' current range represented by the } \\
\text { intersection of predicted future (2050) and current } \\
\text { ranges. }\end{array}$ \\
\cline { 2 - 3 } & $\begin{array}{l}\text { D4. Occurrence of Protected } \\
\text { Areas in Modeled Future Range }\end{array}$ & $\begin{array}{l}\text { Percent of species' predicted future (2050) range } \\
\text { represented by designated conservation areas that are } \\
\text { likely to provide conditions suitable for viable populations } \\
\text { of the species. }\end{array}$ \\
\hline
\end{tabular}

\subsection{Calculating species' climate change vulnerability at range-wide and local scales}

Species' vulnerability to climate change was assessed both range-wide and for all Federal land parcels residing within species' ranges. Species' ranges were characterized via a process similar to that used by Sperry et al.

(2016), which relied on county-level occurrence data sourced from NatureServe Explorer and the USFWS Environmental Conservation Online System (ECOS). Given the large ranges of several species assessed in this effort, all spatial data were projected to Alber's Equal Area Conic. Spatial data for Federal lands were sourced from the U.S. Geological Survey (USGS) National Map.* This dataset includes lands owned or administered by the Federal Government, including the Bureau of Land Management (BLM), Bureau of Reclamation, Forest Service, DoD, USFWS, National Park Service, Tennessee Valley Authority, and other agencies.

Geographic specificity in the NS CCVI is typically captured within factors related to species' direct and indirect exposure to climate change. Per available tool guidelines, direct exposure to future climate change was evaluated in terms of average temperature and moisture availability projected for the year 2050. Climate data used in the index were sourced from

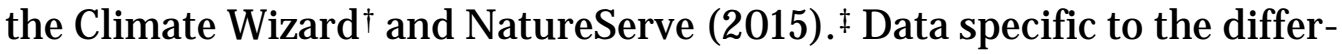
ent species' ranges and relevant Federal lands were extracted from these spatial layers using ArcGIS 10.2.2 (ESRI 2016).

Indirect exposure to climate change is assessed in the NS CCVI via three factors: sea-level change, distribution relative to barriers, and predicted impact of land use changes resulting from human response to climate

\footnotetext{
* http://nationalmap.gov/small_scale/mld/fedlanp.html

+ www.climatewizard.org

‡ www.natureserve.org/conservation-tools/climate-change-vulnerability-index
} 
change (Table 2). This effort assessed geographic specificity in climate change vulnerability only for the two former indirect exposure factors as little information about planned human response to climate change is broadly available.

\subsubsection{Sea-level change}

The impact of anticipated sea-level change on species' vulnerability at range-wide and local scales was assessed using coastal vulnerability index data acquired from the USGS Coastal Change Hazard Portal.* The index ranks the relative susceptibility of U.S. coasts to sea-level rise within four categories (low, moderate, high, and very high) using information on geomorphology, regional coastal slope, tide range, wave height, relative sealevel rise, and shoreline erosion and accretion rates (Thieler and HammarKlose 2000). The four categories of the index were matched to the four assessment categories of this NS CCVI factor by calculating the percentages of the assessment areas represented by any of the three highest index categories (i.e., moderate, high, and very high) and by using those percentages to evaluate exposure to sea-level rise as described in the NS CCVI guidelines (Young et al. 2015). A quantitative assessment of this map-based factor was performed within ArcGIS 10.2.2.

\subsubsection{Anthropogenic barriers}

Distribution relative to anthropogenic barriers was characterized by calculating the percent of the species' ranges represented by developed (i.e., developed open space, developed low intensity, developed medium intensity, and developed high intensity) pasture/ hay and cultivated crop cover types within the 2011 National Land Cover Dataset (Homer et al. 2015). This factor was also evaluated as a local or site-specific factor by calculating the percentage of land represented by these same cover types within $50 \mathrm{~km}$ buffers of Federal lands. These range-wide and local percentages were matched to corresponding assessment categories in the vulnerability index tool based on landscape ecology applications of percolation theory (Stauffer 1985, O’Neill et al. 1988, With and Crist 1995) (Table3).

* http://marine.usgs.gov/coastalchangehazardsportal 
Table 3. Anthropogenic barriers categories and the binned percentages of species' range-wide and local scale (i.e., $50 \mathrm{~km}$ buffers of Federal lands) assessment areas represented by developed, pasture/hay and cultivated crop cover types within the 2011 National Land Cover Dataset that were used to characterize them.

\begin{tabular}{|l|c|}
\hline Assessment Categories & $\begin{array}{c}\text { Percentage of Species' Ranges } \\
\text { and Federal Lands Buffers }\end{array}$ \\
\hline Greatly Increase Vulnerability & $>50 \%$ \\
\hline Increase Vulnerability & $30-50 \%$ \\
\hline Somewhat Increase Vulnerability & $10-30 \%$ \\
\hline Neutral & $<10 \%$ \\
\hline
\end{tabular}

Arguably, other factors related to species' sensitivity and adaptive capacity could also be evaluated spatially in the NS CCVI if information were available, including factors related to spatial variation in population genetic variation, competition from native or non-native species, and predicted sensitivity to temperature and moisture changes (Table 2). In this effort, spatially explicit information for most of these factors was unavailable, but species' predicted sensitivity to temperature and moisture changes were evaluated spatially. Specifically, the process for calculating the factors associated with historical thermal and hydrological niches (i.e., exposure to past variations in temperature and moisture) was slightly altered from the NS CCVI guidelines for use at the local scale of Federal land parcels.

\subsubsection{Historical thermal and hydrological niche}

The NS CCVI guidelines for the factors associated with historical thermal and hydrological niche suggest that average annual historic precipitation should be evaluated over a broad-scale, i.e., the entire range of species. However, many rareand at-risk species have very small ranges, which might lead one to identify little exposure to historical climate variation and thereby assume that the species have a higher vulnerability than would more wide-ranging species. Yet there is growing evidence that many endemic species with small ranges have persisted over long periods through extreme changes in climate within refugia (e.g., Wall et al. 2010, J ansson 2003). Moreover, there is some disagreement about whether broad-ranging species are inherently more robust to climate change than species with small ranges since local adaptation and gene flow can have important counter intuitive effects on range dynamics (Atkins and Travis 2010, Schiffers et al. 2012). Therefore, to make this factor more geographically specific and relevant in this multiscale assessment, estimates of historical thermal and precipitation variation were calculated not only across species' ranges, but also locally for Federal lands. Range-wide estimates for these two factors followed the NSCCVI guidelines (see Young et al. 2015, Appendix 3), but the 
process for local estimates differed. Local estimates of species' exposure to historical thermal variation for specific Federal lands were sourced from the Climate Wizard historic temperature variation map, but the criterion related to $>10 \%$ of a species' range was necessarily omitted. Similarly, local estimates of the species' exposure to historical precipitation variation were sourced from the available historic precipitation map, but individual site-specific estimates were calculated as the difference between the range-wide maximum historical precipitation and the local mean historical precipitation.

The remaining aspatial NS CCVI factors, which are primarily associated with species' sensitivity and adaptive capacity, were synthesized from peer-reviewed journal articles, agency generated reports, and summaries of species' life histories and ecological traits available within NatureServe Explorer and ESA listing documents available from USFWS ECOS. Appendices A and B, respectively, include the sources of information and the values used for each factor and species.

\subsection{Assessing species' climate change vulnerabilities across Federal lands and agencies}

The occurrence of species' populations on Federal lands, which in principle offer the highest degree of protections, is considered during ESA listing decisions. Given the threats of climate change, thelong-term suitability of these Federal land holdings for species conservation is also increasingly being evaluated during listings. Therefore, an evaluation of species' climate change vulnerabilities across Federal lands within the species ranges was conducted. Two different approaches were adopted. First, simple graphical summaries were generated to depict the areas within different NSCCVI categories under management by the various Federal land management agencies for each species. These areas were calculated from the species' vulnerabilities estimated for all of the Federal land parcels (see Section 2.2 above). Second, the oontribution that Federal lands are potentially able to make to each species' range-wide conservation in the face of climate change was evaluated. For example, different species' havevariable amounts of Federal lands within their ranges due not only to differences in overall range size, but also to spatial variation in the location of Federal lands and species' ranges across the United States. Moreover, species' climate change vulnerabilities on Federal lands across their ranges are likely variable due to spatial variation in the magnitude of climate change projected across the country, and to local or regional influences on species' exposure and adaptive capacity (e.g., sea-level rise, anthropogenic barriers). These two important aspects were evaluated by identifying the total area of Federal lands 
across each species' range, and by using a derived index characterizing species' climate change vulnerabilities for each of the Federal lands within their range. The index was calculated as the sum of the vulnerability adjusted percent area represented by Federal land parcels within a species range, where the site-specific NSCCVI vulnerability estimates were incorporated as a multiplier. Table 4 lists the multipliers applied for the five different vulnerability categories. These multipliers can be thought of as characterizing the relative reduction in the suitability or carrying capacity of Federal lands for a given species dueto climate change. For example, two species might have the same range-wide climate change vulnerability, but might also have very different vulnerabilities for the Federal lands within their ranges. Arguably, species with higher vulnerabilities on Federal lands warrant greater conservation concern and action to support climate change adaptation. To have the index vary positively with vulnerability (e.g., high index value with high vulnerability on Federal lands within a species' range), the sum of the vulnerability adjusted percent area of Federal lands within a species' range was subtracted from 100 . This resulted in index values that potentially rangefrom 100 to 0 (zero).

Table 4. Multipliers used to characterize the relative reduction in the suitability or carrying capacity of Federal lands occurring within species' ranges due to climate change vulnerability. The percent area of each Federal land parcel within species' ranges was subjected to the multiplier associated with the NatureServe Climate Change Vulnerability Categories.

\begin{tabular}{|l|c|}
\hline NatureServe Climate Change Vulnerability Categories & Multiplier \\
\hline Extremely vulnerable (EV) & 0.0 \\
\hline Highly vulnerable (HV) & 0.33 \\
\hline Moderately vulnerable (MV) & 0.66 \\
\hline Less vulnerable (LV) & 1.0 \\
\hline Insufficient evidence (IE) & Not Applicable \\
\hline
\end{tabular}

\subsection{A multiscale index of species vulnerability}

A multiscale index of species' climate change vulnerability was generated by combining the species' climate change vulnerabilities estimated at the different scales. This was accomplished by coding the categorical outputs of the NS CCVI tool at both range-wide and local scales, and then combining these values with the index of vulnerability on Federal lands (see Section 2.2 above). Specifically, the NS CCVI outputs were coded as:

- extremely vulnerable $=1$

- highly vulnerable $\quad=0.75$

- moderately vulnerable $=0.5$

- less vulnerable $\quad=0.25$. 
Although the NS CCVI outputs are a categorical data type, they are arguably also inherently ordinal. The choice to go one step further and apply interval data values facilitates greater mathematical manipulation, and follows the strategy taken by other users of the NS CCVI tool (e.g., Reese and Noss 2014, Tuberville et al. 2015). Then the values of the index of vulnerability on Federal lands were standardized to also range from 0 (zero) to 1 by dividing each by the maximum (i.e., 63.5 for R. pretiosa). Weights were then applied to the vulnerabilities at these three scales to reflect their hierarchical importance for determining species' multiscale vulnerability (range-wide $=3$, Federal lands $=2$, installation $=1$ ). The products of the vulnerability values and weights at each scale were then multiplied to generate a multiscale vulnerability index. For example, R. pretiosa, which was found to be highly vulnerable range-wide and on J oint Base LewisMcCord, had a multiscale climate change vulnerability value of:

$$
3.37=((0.75 * 3) \star((63.5 / 63.5) \star 2) *(0.75 * 1))
$$

\subsection{Assessing species climate change vulnerabilities across the Army}

Identifying the species' climate change vulnerabilities that are likely to most impact the Army across multiple installations is also of interest. Such information can be used in decision making and in programmatic planning and coordination with regulators or partner agencies. Since species' climate change vulnerabilities for all Federal land parcels were estimated (see Section 2.2), the vulnerabilities specifically associated with Army facilities could be used to generate a summary metric for comparisons between species. An approach similar to that described above for assessing species' multiscale vulnerability was employed. Specifically, the local scale vulnerabilities were summed for all Army installations within the species' ranges. This sum was then multiplied by the weighted range-wide vulnerability and the weighted standardized values of the index of vulnerability on Federal lands, as above. For example, the local climate change vulnerability of Myotis septentrionalis was calculated as moderately vulnerable on nine installations and less vulnerable on 21 installations. When combined with the weighted range-wide and Federal lands vulnerabilities, the estimated Army-wide vulnerability for M. septentrionalis is:

$$
0.93=[(3 * 0.25) *(2 * 0.06) *(1 *(9 * 0.5)+(21 * 0.25))]
$$




\subsection{Ranking installations based on emerging climate change vulnerabilities}

The Army is also interested in identifying the impact of future climate change on installations to generate information about long-term sustainability that can be used to make diverse decisions such as training mission assignments and base realignment and closure. Increased conservation responsibilities related to Federally listed species is one potential impact of climate change on installations. Wilhoit et al. (2016) proposed a simple method of ranking installations based on potential impacts of climate change-related listed and at-risk species management on training land use. However, their approach did not include any specific information about species' climate change vulnerabilities, but instead used the number of species on installations, the conservation status of these species (i.e., Federally listed, proposed for listing, and at-risk), listing probabilities of different taxonomic groups, and installation area. Effectively, their ranking metric calculated a status and probability of a listing adjusted estimate of at-risk and listed species density.

This effort adopted a different, but potentially complementary, approach to characterize the anticipated relative increase in climate change-related conservation responsibilities among installations. The values calculated for species' multiscale vulnerabilities described above (Section 2.4) were summed for each of the five case study installations. For example, the multiscale vulnerabilities of A. spragueii, C. americanus occidentalis and Z. hudsonius luteus on Fort Bliss were 0.00, 0.28, and 1.11, respectively. When summed, the aggregate vulnerability of species on the installation equaled 1.39. Since only the 16 target species that have been recently listed or that are under review for listing were included in the calculations (and not all of the listed species currently found on the various installations), the aggregate species vulnerabilities on the installations summarized here can be interpreted as an assessment of the emerging increase in climate change-related conservation responsibilities. 


\section{Results and Discussion}

\subsection{Species' range-wide climate change vulnerabilities}

There were modest differences in range-wide climate change vulnerability among the 16 species examined in this effort: only one species was classified as highly vulnerable (HV), seven were classified as moderately vulnerable (MV), and eight were classified as less vulnerable (LV) (Table 5). For all installations having more than one species, range-wide vulnerabilities of the represented species varied. For example, range-wide vulnerabilities of the seven species on J oint Base Lewis-McCord ranged from highly vulnerable to less vulnerable. This suggests that species' climate change vulnerabilities, even at the range-wide scale, are likely a useful criterion for prioritizing conservation efforts.

The index of species' vulnerabilities on Federal lands varied from a high of 63.4 for the Oregon spotted frog (Rana pretiosa) to a low of 0.30 for the Midwestern temperate avian migrant Anthus spragueii (Table 5). The area of Federal lands occurring within the ranges of the study species exhibited large differences; the southeastern woody shrub Amorpha georgiana was found to have the smallest amount of Federal lands within its range (653 $\left.\mathrm{km}^{2}\right)$ while A. spragueii had the largest $\left(705,817 \mathrm{~km}^{2}\right)$ (Table 5). These differences were not unanticipated given the variation in the size of species' ranges. The Federal lands area within species' ranges and the index of vulnerabilities on Federal lands were not correlated (Pearson's radj $=0.139$ ), suggesting that the latter provides additional information useful for prioritizing conservation species. When all three range-wide variables were used sequentially to rank the various species (i.e., range-wide vulnerability first, index of vulnerability on Federal lands second, Federal lands area within species ranges third), it was found that:

1. R. pretiosa retained its rank of highest vulnerability.

2. Among moderately vulnerable species, the southeastern woody shrub Lindera subcoriacea exhibited the greatest overall climate change vulnerability and the fossorial rodent Thomomys mazama glacialis exhibited the lowest vulnerability.

3. Among the seven less vulnerable species, the southeastern herbaceous aquatic plant Nuphar lutea sagittifolia exhibited the greatest overall climate change vulnerability and A. spragueii the lowest (Table 5). 
This simple approach to identifying species' relative range-wide climate change variability is appealing in that it transparently retains the information about the three variables used in ranking. However, where a large number of species is being considered, it could become cumbersome and it might be beneficial to use an approach that generates a single metric (Section 2.4).

Table 5. Ranked list of species' range-wide climate change variability, based on sequential evaluation of index of vulnerability on Federal lands, and Federal lands area within species' ranges.

\begin{tabular}{|l|c|c|c|}
\hline Species & $\begin{array}{c}\text { Range-wide climate } \\
\text { change vulnerability }\end{array}$ & $\begin{array}{c}\text { Index of vulnerability } \\
\text { on Federal lands }\end{array}$ & $\begin{array}{c}\text { Federal lands area }\left(\mathbf{k m}^{2}\right) \\
\text { within species' range }\end{array}$ \\
\hline Rana pretiosa & HV & 63.5 & 227173.8 \\
\hline Lindera subcoriacea & MV & 50.0 & 9158.4 \\
\hline Zapus hudsonius luteus & MV & 47.0 & 117437.6 \\
\hline Amorpha georgiana & MV & 34.0 & 652.6 \\
\hline Thomomys mazama pugetensis & MV & 34.0 & 999.3 \\
\hline Thomomys mazama tumuli & MV & 34.0 & 999.3 \\
\hline Thomomys mazama yelmensis & MV & 34.0 & 999.3 \\
\hline Thomomys mazama glacialis & MV & 34.0 & 3783.1 \\
\hline Nuphar lutea sagittifolia & LV & 31.7 & 1804.4 \\
\hline Lobelia boykinii & LV & 25.4 & 10105.3 \\
\hline Coccyzus americanus occidentalis & LV & 23.7 & 12295.6 \\
\hline Euphydryas editha taylori & LV & 13.9 & 38063.2 \\
\hline Eremophila alpestris strigata & LV & 4.6 & 224643.1 \\
\hline Myotis septentrionalis & LV & 4.0 & 2374.7 \\
\hline Isoetes hyemalis & LV & 3.4 & 705816.8 \\
\hline Anthus spragueii & LV & 0.3 & \\
\hline
\end{tabular}

\subsection{Species' climate change vulnerabilities across Federal agency lands}

The local climate change vulnerabilities of the target species on Federal lands across their ranges exhibited striking differences in terms of the agencies represented, the areas managed by different agencies, and the vulnerability categories represented (Figures 1 to 15). The number of nonDoD Federal land management agencies that could serve as potential partners for the different species ranged from nine to one. As might be expected, species that have the largest numbers of non-DoD Federal land managers included those with the largest geographical ranges (e.g., Myotis septentrionalis with nine and Anthus spragueii with eight agencies). Similarly, species having the smallest numbers of non-DoD Federal land management 
agencies included those with the smallest geographical ranges (e.g., A. georgiana, T. mazama pugentensis, T. mazama tumuli, and T. mazama yelmensis were only represented on lands of one other agency)

The percent of the Federal land area within species' ranges under DoD management also exhibited a large amount of variation for the suite of study species (range $=1-94 \%$ ) (Figures 1 to 15 ). The species having the lowest percent of Federal lands within its range under DoD management were E. alpestris strigata and R. pretiosa, at 1 and $2 \%$, respectively. The species with the largest percent of Federal lands under DoD management was A. georgiana (94\%), but T. mazama pugentensis, T. mazama tumuli, and T. mazama yelmensis were also notably high at $64 \%$. Correspondingly, there is more land under DoD management within the ranges of these species than any other Federal agency. This is also true for the southeastern wetland obligate plants Isoetes hyemalis and Lobelia boykinii, making DoD the leading Federal management agency for roughly one-third of the 16 study species. In comparison, the BLM leads for three and the Forest Service leads for seven species.

Spatial variation in vulnerabilities among Federal lands parcels were observed for all but two species (A. georgiana and T. mazama subspecies), which have small geographic ranges. Species' climate change vulnerabilities on DoD relative to other Federal agency lands also varied to differing degrees among species (Figures 1 to 15). For the six species having DoD as the primary Federal land manager across their range, vulnerabilities on DoD lands were higher for one species, lower for one species, and comparable for the four other species than on lands of the next largest agency. For the 10 species for which DoD is not the primary Federal land manager across their range, climate change vulnerabilities on DoD lands relative to the larger agency were higher for four species, lower for three species, and comparable for the other three species. 
Figure 1. Federal land area $\left(\mathrm{km}^{2}\right)$ within the range of Amorpha georgiana (Georgia leadplant) by agency and vulnerability categories.

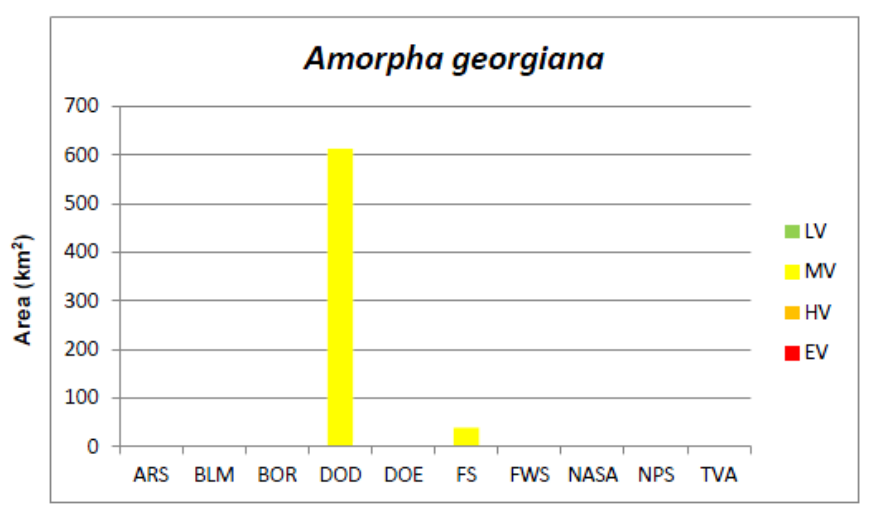

Federal Agency

Figure 2. Federal land area $\left(\mathrm{km}^{2}\right)$ within the range of Anthus spragueii (Sprague's pipet) by agency and vulnerability categories.

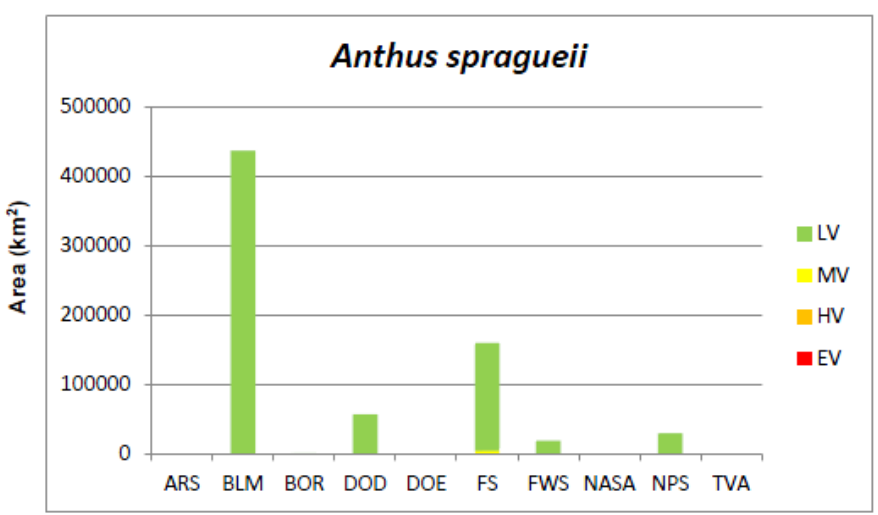

Federal Agency

Figure 3. Federal land area $\left(\mathrm{km}^{2}\right)$ within the range of Coccyzus americanus occidentalis (Western yellow-billed cuckoo) by agency and vulnerability categories.

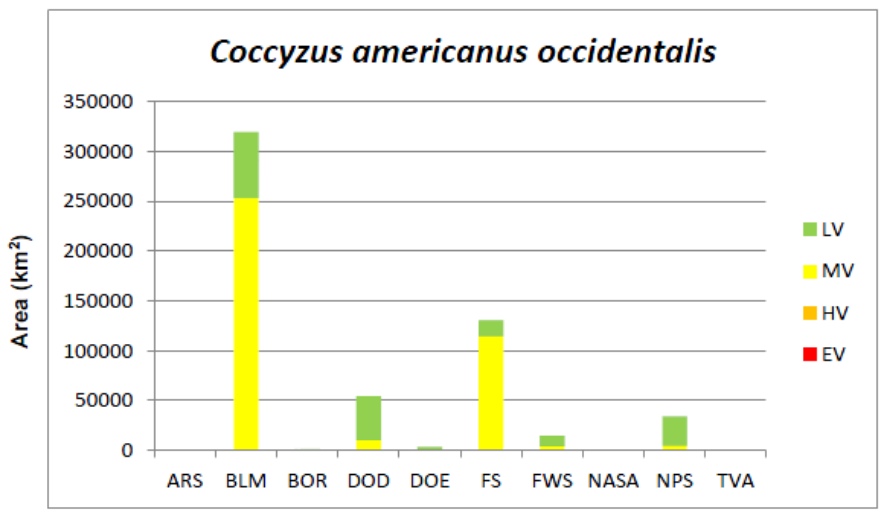

Federal Agency

Vulnerability categories are less vulnerable (LV), moderately vulnerable (MV), highly vulnerable (HV) and extremely vulnerable (EV). Federal land management agencies include: Agricultural Research Service (ARS), Bureau of Land Management (BLM), Bureau of Reclamation (BOR), Department of Defense (DoD), Department of Energy (DOE), Forest Service (FS), Fish and Wildlife Service (FWS), National Aeronautics and Space Administration (NASA), National Park Service (NPS), and Tennessee Valley Authority (TVA). 
Figure 4. Federal land area $\left(\mathrm{km}^{2}\right)$ within the range of Eremophila alpestris strigata (streaked horned lark) by agency and vulnerability categories.

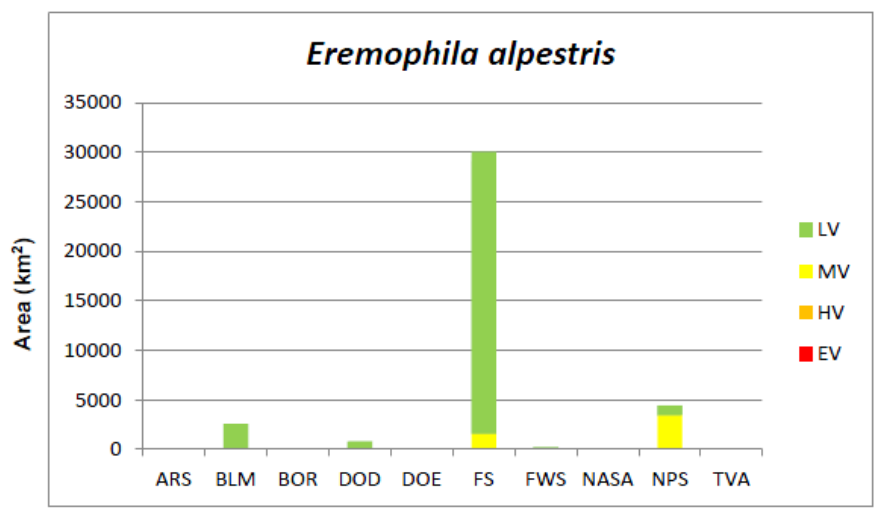

Federal Agency

Figure 5. Federal land area $\left(\mathrm{km}^{2}\right)$ within the range of Euphydryas editha taylori (Taylor's checkerspot) by agency and vulnerability categories.

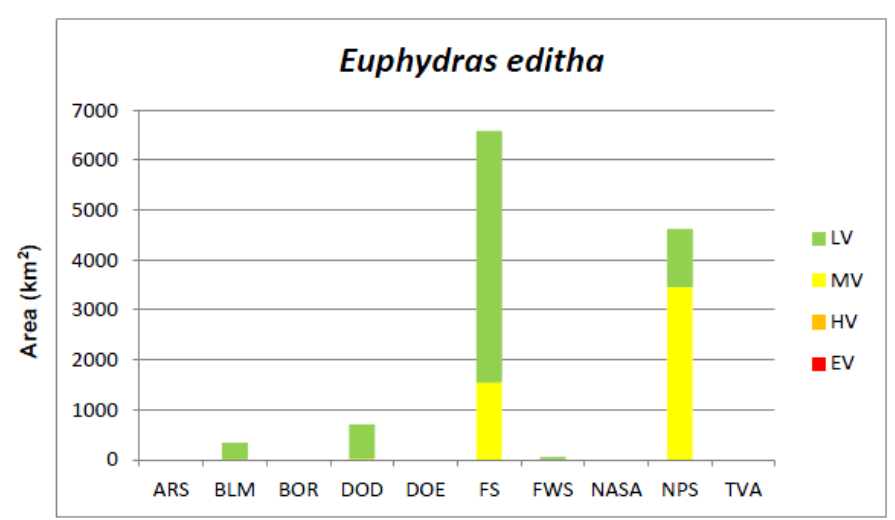

Federal Agency

Figure 6. Federal land area $\left(\mathrm{km}^{2}\right)$ within the range of Isoetes hyemalis (winter quillwort) by agency and vulnerability categories.

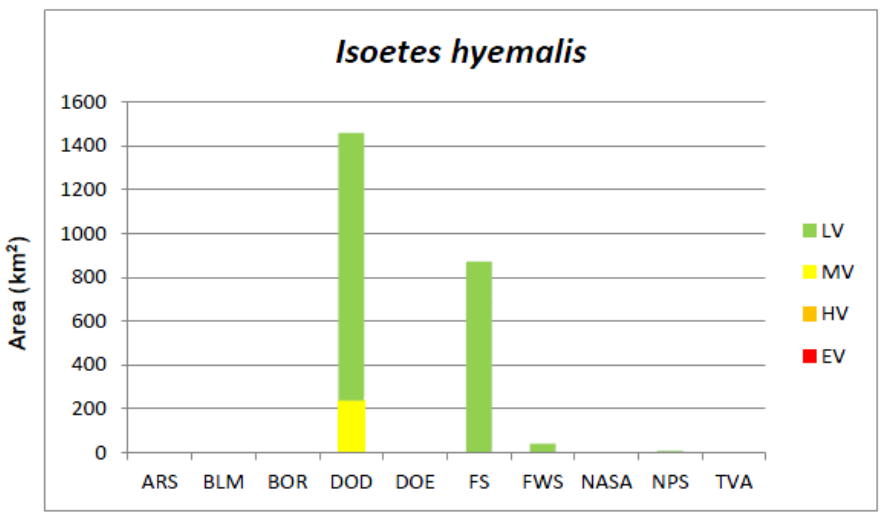

Federal Agency

Vulnerability categories are less vulnerable (LV), moderately vulnerable (MV), highly vulnerable (HV) and extremely vulnerable (EV). Federal land management agencies include: Agricultural Research Service (ARS), Bureau of Land Management (BLM), Bureau of Reclamation (BOR), Department of Defense (DoD), Department of Energy (DOE), Forest Service (FS), Fish and Wildlife Service (FWS), National Aeronautics and Space Administration (NASA), National Park Service (NPS), and Tennessee Valley Authority (TVA). 
Figure 7. Federal land area $\left(\mathrm{km}^{2}\right)$ within the range of Lindera subcoriacea (bog spicebush) by agency and vulnerability categories.

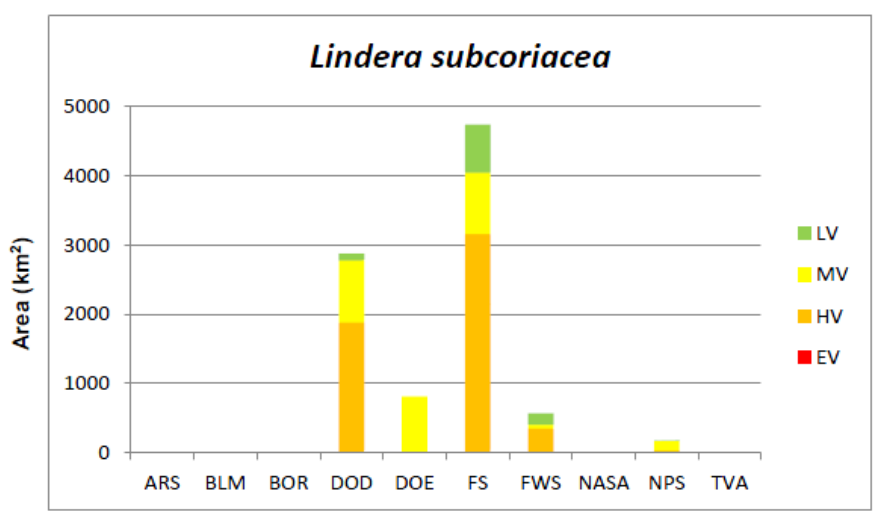

Federal Agency

Figure 8. Federal land area $\left(\mathrm{km}^{2}\right)$ within the range of Lobelia boykinii (Boykin's lobelia) by agency and vulnerability categories.

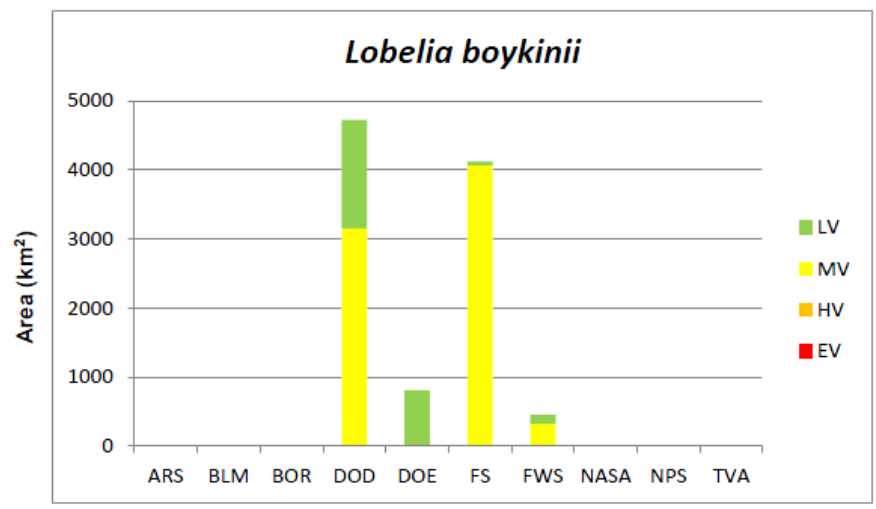

Federal Agency

Figure 9. Federal land area $\left(\mathrm{km}^{2}\right)$ within the range of Nuphar lutea sagittifolia (Cape Fear spatterdock) by agency and vulnerability categories.

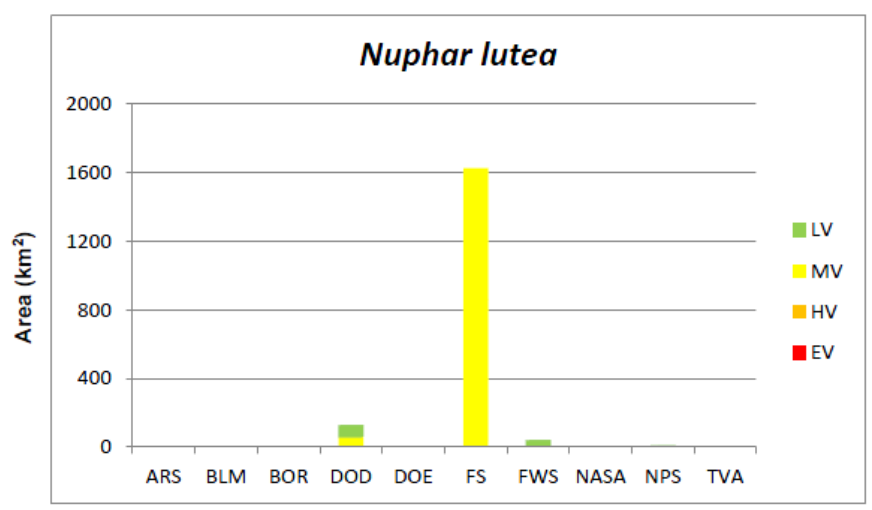

Federal Agency

Vulnerability categories are less vulnerable (LV), moderately vulnerable (MV), highly vulnerable (HV) and extremely vulnerable (EV). Federal land management agencies include: Agricultural Research Service (ARS), Bureau of Land Management (BLM), Bureau of Reclamation (BOR), Department of Defense (DoD), Department of Energy (DOE), Forest Service (FS), Fish and Wildlife Service (FWS), National Aeronautics and Space Administration (NASA), National Park Service (NPS), and Tennessee Valley Authority (TVA). 
Figure 10. Federal land area $\left(\mathrm{km}^{2}\right)$ within the range of Myotis septentrionalis (northern long-eared bat) by agency and vulnerability categories.

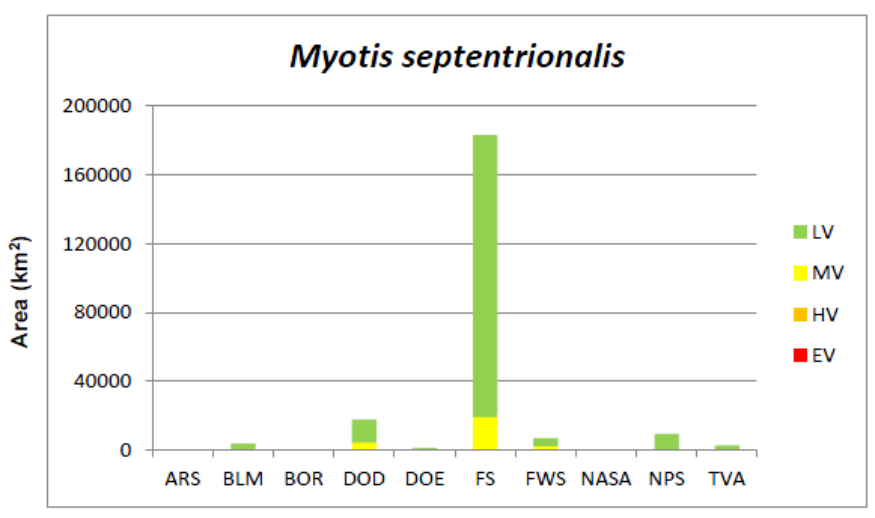

Federal Agency

Figure 11. Federal land area $\left(\mathrm{km}^{2}\right)$ within the range of Rana pretiosa (Oregon spotted frog) by agency and vulnerability categories.

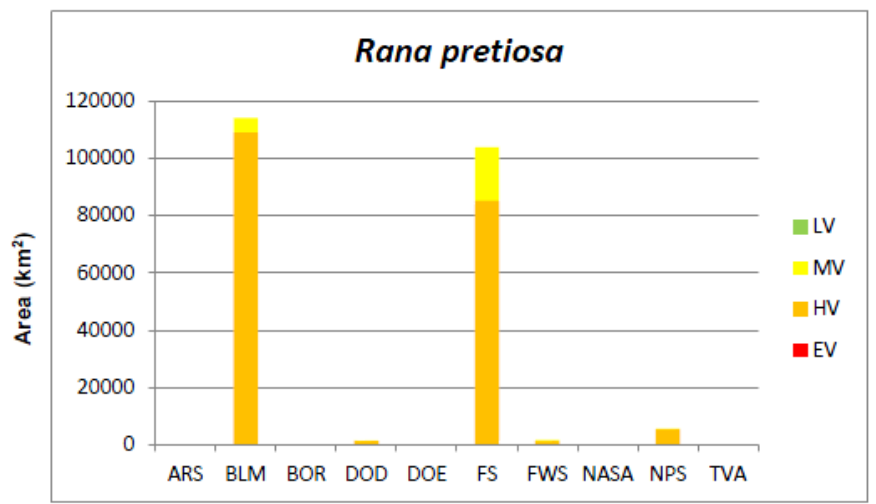

Federal Agency

Figure 12. Federal land area $\left(\mathrm{km}^{2}\right)$ within the range of Thomomys mazama glacialis (Roy Prairie pocket gopher) by agency and vulnerability categories.

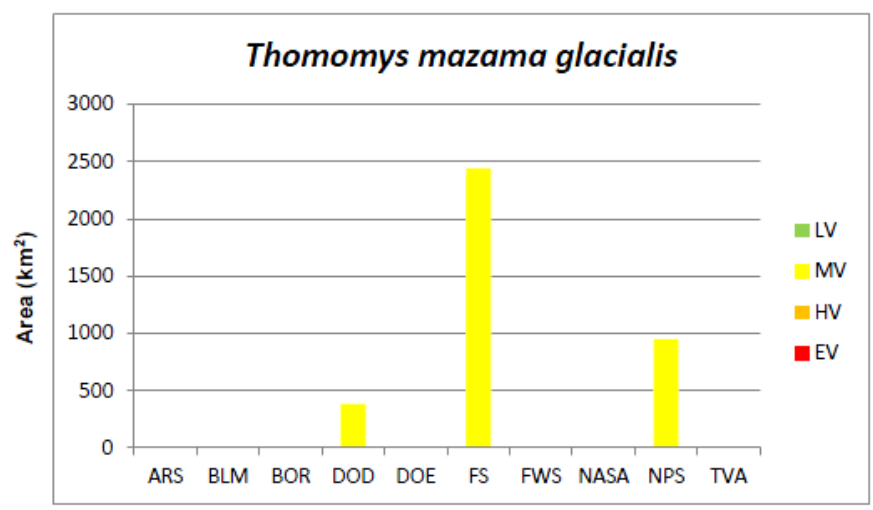

Federal Agency

Vulnerability categories are less vulnerable (LV), moderately vulnerable (MV), highly vulnerable (HV) and extremely vulnerable (EV). Federal land management agencies include: Agricultural Research Service (ARS), Bureau of Land Management (BLM), Bureau of Reclamation (BOR), Department of Defense (DoD), Department of Energy (DOE), Forest Service (FS), Fish and Wildlife Service (FWS), National Aeronautics and Space Administration (NASA), National Park Service (NPS), and Tennessee Valley Authority (TVA). 
Figure 13. Federal land area $\left(\mathrm{km}^{2}\right)$ within the range of Thomomys mazama pugetensis (Olympia pocket gopher) by agency and vulnerability categories.

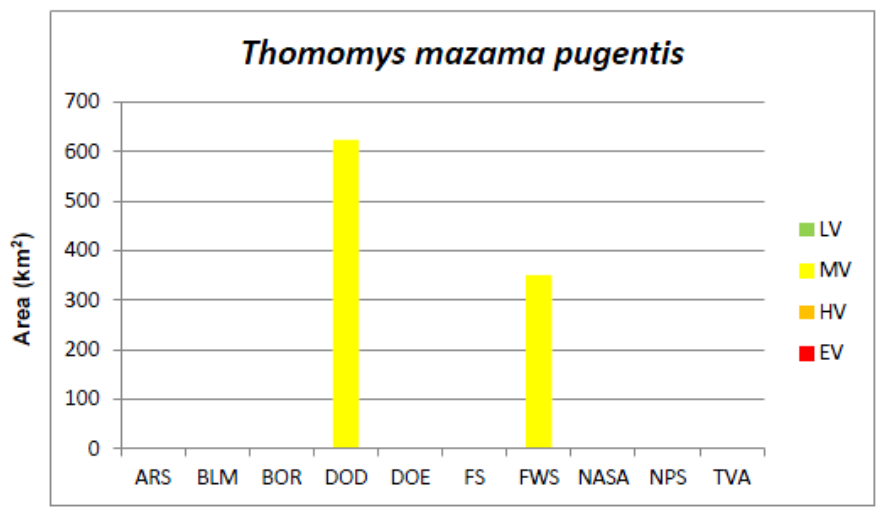

Federal Agency

Figure 14. Federal land area $\left(\mathrm{km}^{2}\right)$ within the range of Thomomys mazama tumuli (Tenino pocket gopher) by agency and vulnerability categories.

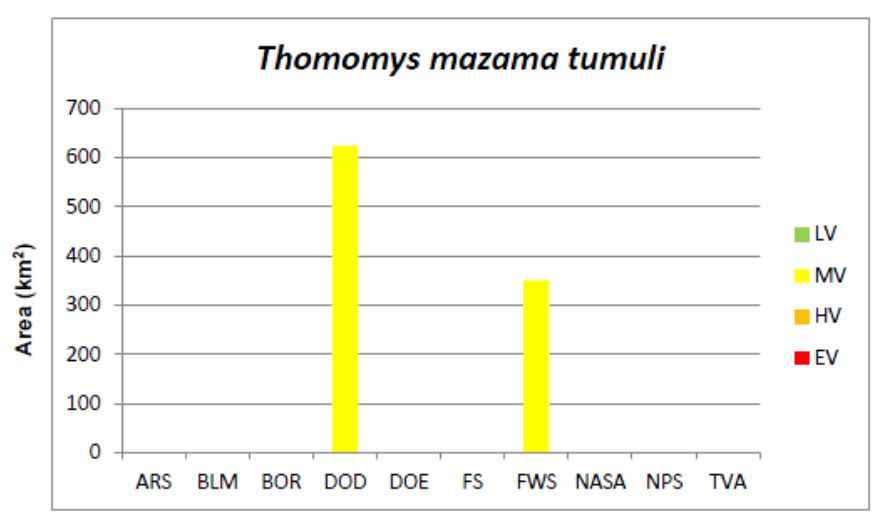

Federal Agency

Figure 15. Federal land area $\left(\mathrm{km}^{2}\right)$ within the range of Zapus hudsonius luteus (New Mexican jumping mouse) by agency and vulnerability categories.

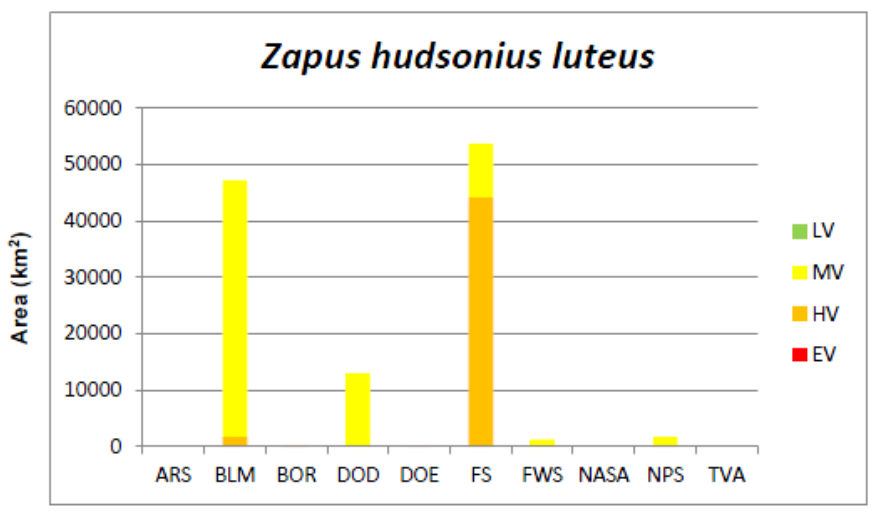

Federal Agency

Vulnerability categories are less vulnerable (LV), moderately vulnerable (MV), highly vulnerable (HV) and extremely vulnerable (EV). Federal land management agencies include: Agricultural Research Service (ARS), Bureau of Land Management (BLM), Bureau of Reclamation (BOR), Department of Defense (DoD), Department of Energy (DOE), Forest Service (FS), Fish and Wildlife Service (FWS), National Aeronautics and Space Administration (NASA), National Park Service (NPS), and Tennessee Valley Authority (TVA). 


\subsection{Species' climate change vulnerabilities on installations}

For the species and installations evaluated here, there was agreement between the range-wide and installation-scale climate change vulnerabilities for all species except the neotropical avian migrant Coccyzus americanus occidentalis, which was found to have a higher installation-specific vulnerability (MV) than range-wide vulnerability (LV) (Tables 5 and 6). Although there are no comparable cases for the species examined here, one can imagine how differences in vulnerabilities at local and range-wide scales could inform management decisions. For example, a species having extremely high vulnerability on an installation, but only moderately vulnerable range-wide and across Federal lands might be a poor candidate for conservation investment compared to a species with moderate local vulnerability, but extremely high vulnerability range-wide and across Federal lands. For the former case, DoD investment will likely have little overall influence on the species' success in response to climate change, whereas in the latter scenario DoD investment may greatly affect the species' conservation and probability of listing.

The general consistency observed between local and range-wide vulnerabilities is likely a consequence of some species' small range sizes, little variability in vulnerability across species' ranges, or the locations of the study installations. In contrast, Tuberville et al. (2015) found that only $42 \%$ of range-wide and regional climate change vulnerability estimates were consistent in an assessment of southeastern amphibian and reptile species. That being said, only a relatively small percentage of their species' ranges overlapped with the regional assessment area ( mean $=2.27 \%$ ).

Table 6. Ranking of species on installations by local (installation-specific) climate change vulnerabilities.

\begin{tabular}{|l|l|l|}
\hline Installation & Species & Local Climate Change Vulnerability \\
\hline Fort Bliss & & \\
\hline & Zapus hudsonius luteus & MV \\
\hline & Coccyzus americanus occidentalis & MV \\
\hline & Anthus spragueii & LV \\
\hline & & \\
\hline Fort Bragg & Amorpha georgiana & MV \\
\hline & Lindera subcoriacea & MV \\
\hline & Isoetes hyemalis & LV \\
\hline & Myotis septentrionalis & LV \\
\hline & Lobelia boykinii & LV \\
\hline & Nuphar lutea sagittifolia & LV \\
\hline
\end{tabular}




\begin{tabular}{|l|l|l|}
\hline Installation & Species & Local Climate Change Vulnerability \\
\hline Fort Drum & & \\
\hline & Myotis septentrionalis & LV \\
\hline Joint Base Lewis-McCord & & \\
\hline & Rana pretiosa & HV \\
\hline & Thomomys mazama pugetensis & MV \\
\hline & Thomomys mazama tumuli & MV \\
\hline & Thomomys mazama yelmensis & MV \\
\hline & Thomomys mazama glacialis & MV \\
\hline & Eremophila alpestris strigata & LV \\
\hline Fort Riley & Euphydryas editha taylori & LV \\
\hline & & \\
\hline & Myotis septentrionalis & LV \\
\hline
\end{tabular}

\subsection{Multiscale index of species' climate change vulnerabilities}

Species' multiscale climate change vulnerabilities ranged from 3.37 for R. pretiosa to 0.00 for A. spragueii. Values were roughly clustered into three groups that corresponded to the three categories assigned to the species' range-wide vulnerabilities. Moreover, the order of the species' rankings was largely consistent with that found for range-wide vulnerabilities (Table 5), except for C. americanus occidentalis, which replaced N. lutea sagittifolia in the ninth highest rank.

Although estimating species' climate change vulnerabilities at different scales (Section 2.2) can provide unique insights about the need and appropriateness of different levels of conservation investment for diverse species, interpreting the relative importance of differences in values among vulnerabilities estimated at several scales becomes challenging when many species are being considered. The approach to estimating an integrated multiscale vulnerability index that was demonstrated here offers a useful solution. Note that, although the weighting scheme applied in this effort assumed that the importance of species' local scale vulnerabilities (Table 7) is secondary to vulnerabilities at larger scales, the approach is flexible, and accommodates different weighting schemes as needed.

Table 7. Ranking of species on installations by local (installation-specific) climate change vulnerabilities.

\begin{tabular}{|l|c|}
\hline Species & Multiscale Climate Change Vulnerability \\
\hline Rana pretiosa & 3.37 \\
\hline Lindera subcoriacea & 1.18 \\
\hline Zapus hudsonius luteus & 1.11 \\
\hline Amorpha georgiana & 0.80 \\
\hline Thomomys mazama glacialis & 0.80 \\
\hline
\end{tabular}




\begin{tabular}{|l|c|}
\hline Species & Multiscale Climate Change Vulnerability \\
\hline Thomomys mazama pugetensis & 0.80 \\
\hline Thomomys mazama tumuli & 0.80 \\
\hline Thomomys mazama yelmensis & 0.80 \\
\hline Coccyzus americanus occidentalis & 0.28 \\
\hline Nuphar lutea sagittifolia & 0.19 \\
\hline Lobelia boykinii & 0.15 \\
\hline Euphydryas editha taylori & 0.08 \\
\hline Eremophila alpestris strigata & 0.03 \\
\hline Myotis septentrionalis & 0.02 \\
\hline Isoetes hyemalis & 0.02 \\
\hline Anthus spragueii & 0.00 \\
\hline
\end{tabular}

\subsection{Army-wide exposure to potential impacts of species' climate change vulnerabilities}

When species were evaluated for their cumulative climate change vulnerabilities across the Army, the rankings of species changed considerably from vulnerabilities estimated with a range-wide focus (Table 5) changed considerably when they were estimated with a multiscale single installation focus (Table 7). Although R. pretiosa and A. spragueii still exhibited the maximum (3.37) and minimum (0.05) values, respectively, the ranks of the other 14 species changed. Notably, C. americanus occidentalis rose 5 to 7 positions in the ranking.

Considering the estimated values of species' climate change vulnerabilities Army-wide, not just their relative rankings, the perceived degree of vulnerability exhibited by R. pretiosa was reduced while Z. hudsonius luteus and L. subcoriacea retained comparably high values (i.e., $\sim 3$ ). This is a consequence of the latter two species' occurrence on multiple installations.

Sperry, Wall, and Hohmann (2016) also conducted Army-wide assessments of species proposed for ESA listing, except that they focused exclusively on potential impact to Army training. Since their approach did not consider the consequences of climate change on potential future impacts, it is interesting to examine the potential additional effect of climate change vulnerability identified by this approach. Five of the species included in this effort were among the top 20 species they determined most likely to impact Army training (i.e., A. spragueii, L. boykinii, L. subcoriacea, A. georgiana, and M. septentrionalis; ordered from greater to lesser impact). Considering their ranking of species relative to that shown in Tables 
8 and 5, one can see that the climate change vulnerability of L. subcoriacea, and to a lesser extent A. georgiana, have the potential to increase their impacts on Army training beyond that suggested by Sperry, Wall, and Hohmann (2016). It may also offer some reassurance to Army managers to know that climate change vulnerability is not likely to exacerbate the impacts of A. spragueii, L. boykinii, or M. septentrionalis on the Army.

Table 8. Ranked list of species based on climate change vulnerabilities across Army.

\begin{tabular}{|l|c|}
\hline Species & $\begin{array}{c}\text { Army-wide Climate } \\
\text { Change Vulnerability }\end{array}$ \\
\hline Rana pretiosa & 3.37 \\
\hline Zapus hudsonius luteus & 3.33 \\
\hline Lindera subcoriacea & 2.95 \\
\hline Coccyzus americanus occidentalis & 2.28 \\
\hline Amorpha georgiana & 1.61 \\
\hline Thomomys mazama glacialis & 1.61 \\
\hline Thomomys mazama pugetensis & 1.61 \\
\hline Thomomys mazama tumuli & 1.61 \\
\hline Thomomys mazama yelmensis & 1.61 \\
\hline Myotis septentrionalis & 0.93 \\
\hline Lobelia boykinii & 0.75 \\
\hline Nuphar lutea sagittifolia & 0.56 \\
\hline Euphydryas editha taylori & 0.25 \\
\hline Eremophila alpestris strigata & 0.11 \\
\hline Isoetes hyemalis & 0.08 \\
\hline Anthus spragueii & 0.05 \\
\hline
\end{tabular}

\subsection{Installation exposure to potential impacts of multiple species' climate change vulnerabilities}

The aggregate index of installations' potential exposure to emerging conservation challenges associated with species' climate change vulnerabilities varied from 6.69 to 0.02 for J oint Base Lewis-McCord and Forts Drum and Riley, respectively (Table 9). Both Fort Drum and Riley had only a single species represented, M. septentrionalis, whereas J oint Base LewisMcChord (J BLM) had the most at seven. The ranking of installations and their relative values is potentially useful for planning additional funding needs beyond those that might already be identified for installations based on historically listed species. 
These results suggest regional differences in climate vulnerabilities, as far as they may be ascertained by the representative species and installations included here. The Northeast appears to be most vulnerable, followed by the Southeast and the Southwest, while the Midwest and Northeast share comparably low vulnerabilities.

Interestingly, the assessment conducted by Wilhoit et al. (2016) ranked the five common installations in an order similar to that in Table 9, except that Fort Riley was third highest instead of Fort Bliss. Their assessment included a broader set of species (i.e., all listed and at-risk species) than that evaluated in this work. It is unknown whether findings would be comparable for a larger number of installations.

Table 9. Ranked list of study installations based on aggregate index of species' climate change vulnerabilities.

\begin{tabular}{|l|c|}
\hline Installation & $\begin{array}{c}\text { Aggregate Index of Species' } \\
\text { Climate Change Vulnerabilities }\end{array}$ \\
\hline Joint Base Lewis-McCord & 6.69 \\
\hline Fort Bragg & 2.37 \\
\hline Fort Bliss & 1.39 \\
\hline Fort Drum & 0.02 \\
\hline Fort Riley & 0.02 \\
\hline
\end{tabular}




\section{Conclusion and Recommendations}

\subsection{Conclusion}

This work demonstrated a method for generating multiscale climate change vulnerability assessments for species and installations. The approach satisfies DoD's need for consistent assessment methods that can be conducted with broadly available data and that allow meaningful comparisons. This demonstrated approach to multiscale vulnerability assessment is suitable for integrating climate change considerations into installation Integrated Natural Resource Management Plans, for evaluating whether climate changed driven impacts to listed species will likely affect installation resilience, and for strategically identifying potential conservation partners among Federal land managers.

\subsection{Recommendations}

Importantly, the approach to multiscale species' vulnerability assessments demonstrated here also complements recent Army-wide and installation focused evaluations of species' potential impacts on training (Sperry, Wall, and Hohmann 2016). However, it is recommended that the scope of application first be extended to all species and installations across the Army before climate change vulnerabilities can be integrated with these other assessments.

Key among the findings of this effort was the role that DoD (relative to the roles of other Federal land management agencies) may be expected to contribute to species' conservation in the face of climate change. DoD was the leading Federal management agency for roughly one-third of the 16 study species. Where species' vulnerabilities are lower on lands managed by other agencies, it is recommended that the Army seek partnerships that can generate conservation success greater than that to be gained by relying solely on within-the-fenceline approaches. 


\section{Appendix A: Assessment Sources}

Table A-1 lists sources of information used to inform factors in species' vulnerability assessments.

Table A-1. Sources of information used to inform factors in species' vulnerability assessments.

\begin{tabular}{|c|c|c|c|}
\hline Installation & Scientific Name & $\begin{array}{l}\text { Taxonomic } \\
\text { Group }\end{array}$ & Assessment Sources and Notes \\
\hline \multicolumn{4}{|l|}{ Fort Bliss } \\
\hline & Anthus spragueii & Bird & $\begin{array}{l}\text { Ludlow et al. 2015, Davis 2005, Lueders et al. 2006, } \\
\text { Jones 2010, Davis et al. 2013, Rodgers 2013, Kalyn } \\
\text { Bogard and Davis 2014, Muller 2015, NatureServe 2015, }\end{array}$ \\
\hline & $\begin{array}{l}\text { Coccyzus } \\
\text { americanus } \\
\text { occidentalis }\end{array}$ & Bird & Wallace et al. 2013, Farrell 2013, NatureServe 2015 \\
\hline & $\begin{array}{l}\text { Zapus hudsonius } \\
\text { luteus }\end{array}$ & Mammal & $\begin{array}{l}\text { Malaney et al 2012, Frey and Malaney 2009, Wright and } \\
\text { Frey 2014, 2015, Frey 2015, NatureServe } 2015\end{array}$ \\
\hline \multicolumn{4}{|l|}{ Fort Bragg } \\
\hline & $\begin{array}{l}\text { Amorpha } \\
\text { georgiana }\end{array}$ & Vascular plant & Straub and Doyle 2009, NatureServe 2015 \\
\hline & $\begin{array}{l}\text { Lindera } \\
\text { subcoriacea }\end{array}$ & Vascular plant & $\begin{array}{l}\text { Dupont and Kato 1999, Wall et al. 2013, NatureServe } \\
2015\end{array}$ \\
\hline & Lobelia boykinii & Vascular plant & Royo et al. 2008, NatureServe 2015 \\
\hline & Isoetes hyemalis & Vascular plant & $\begin{array}{l}\text { Brunton et al. 1994, Caplen and Werth 2000, NatureServe } \\
2015\end{array}$ \\
\hline & $\begin{array}{l}\text { Nuphar lutea } \\
\text { sagittifolia }\end{array}$ & Vascular plant & NatureServe 2015 \\
\hline & $\begin{array}{l}\text { Myotis } \\
\text { septentrionalis }\end{array}$ & Mammal & $\begin{array}{l}\text { Frick et al. 2010, 2012, Hein 2012, Jones and Rebelo } \\
\text { 2013, Loeb and Winters 2013, Luo et al. 2014, } \\
\text { NatureServe 2015, Pauli et al. } 2015\end{array}$ \\
\hline \multicolumn{4}{|l|}{ Fort Drum } \\
\hline & $\begin{array}{l}\text { Myotis } \\
\text { septentrionalis }\end{array}$ & Mammal & $\begin{array}{l}\text { Frick et al. 2010, 2012, Hein 2012, Jones and Rebelo } \\
\text { 2013, Loeb and Winters 2013, Luo et al. 2014, } \\
\text { NatureServe 2015, Pauli et al. } 2015\end{array}$ \\
\hline \multicolumn{4}{|l|}{ Fort Lewis } \\
\hline & $\begin{array}{l}\text { Eremophila } \\
\text { alpestris strigata }\end{array}$ & Bird & $\begin{array}{l}\text { Pearson and Altman 2005, Anderson and Pearson 2015, } \\
\text { NatureServe } 2015\end{array}$ \\
\hline & $\begin{array}{l}\text { Euphydryas editha } \\
\text { taylori }\end{array}$ & Insect & $\begin{array}{l}\text { Ehrlich et al. 1980, Weiss and Weiss 1998, McLaughlin et } \\
\text { al. 2002, Singer et al. 2008, Diamond et al. 2011, } \\
\text { Radchuk et al. 2013, Bennett et al. 2014, Kharouba et al. } \\
\text { 2014, Caldas 2014, NatureServe } 2015\end{array}$ \\
\hline & Rana pretiosa & Amphibian & $\begin{array}{l}\text { Funk et al. 2008, Blaustein et al. 2010, Blouin et al. 2010, } \\
\text { Bowerman and Pearl 2010, Conlon et al. 2011, McCaffery } \\
\text { and Maxell 2010, Phillipsen et al. 2011, Li et al. 2013, } \\
\text { Ryan et al. 2014, NatureServe } 2015\end{array}$ \\
\hline & $\begin{array}{l}\text { Thomomys } \\
\text { mazama glacialis }\end{array}$ & Mammal & Stinson 2013, NatureServe 2015 \\
\hline
\end{tabular}




\begin{tabular}{|l|l|l|l|}
\hline Installation & Scientific Name & $\begin{array}{l}\text { Taxonomic } \\
\text { Group }\end{array}$ & Assessment Sources and Notes \\
\hline & $\begin{array}{l}\text { Thomomys } \\
\text { mazama } \\
\text { pugetensis }\end{array}$ & Mammal & Stinson 2013, NatureServe 2015 \\
\hline & $\begin{array}{l}\text { Thomomys } \\
\text { mazama tumuli }\end{array}$ & Mammal & Stinson 2013, NatureServe 2015 \\
\hline & $\begin{array}{l}\text { Thomomys } \\
\text { mazama yelmensis }\end{array}$ & Mammal & Stinson 2005, Stinson 2013, NatureServe 2015 \\
\hline Fort Riley & $\begin{array}{l}\text { Myotis } \\
\text { septentrionalis }\end{array}$ & Mammal & $\begin{array}{l}\text { Frick et al. 2010, 2012, Hein 2012, Jones and Rebelo } \\
\text { 2013, Loeb and Winters 2013, Luo et al. 2014, } \\
\text { NatureServe 2015, Pauli et al. 2015 }\end{array}$ \\
\hline
\end{tabular}




\section{Appendix B: Factor Scores}




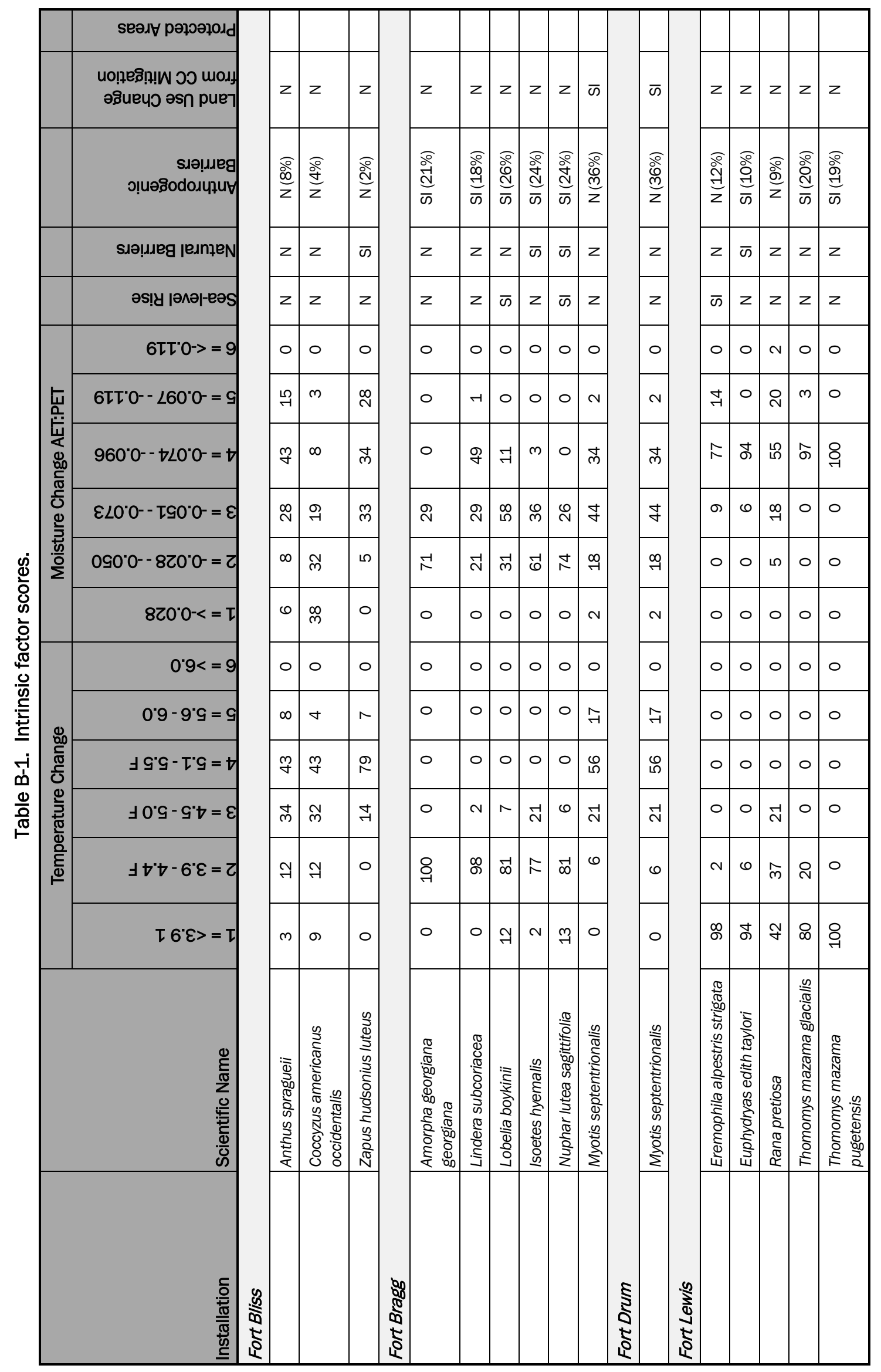




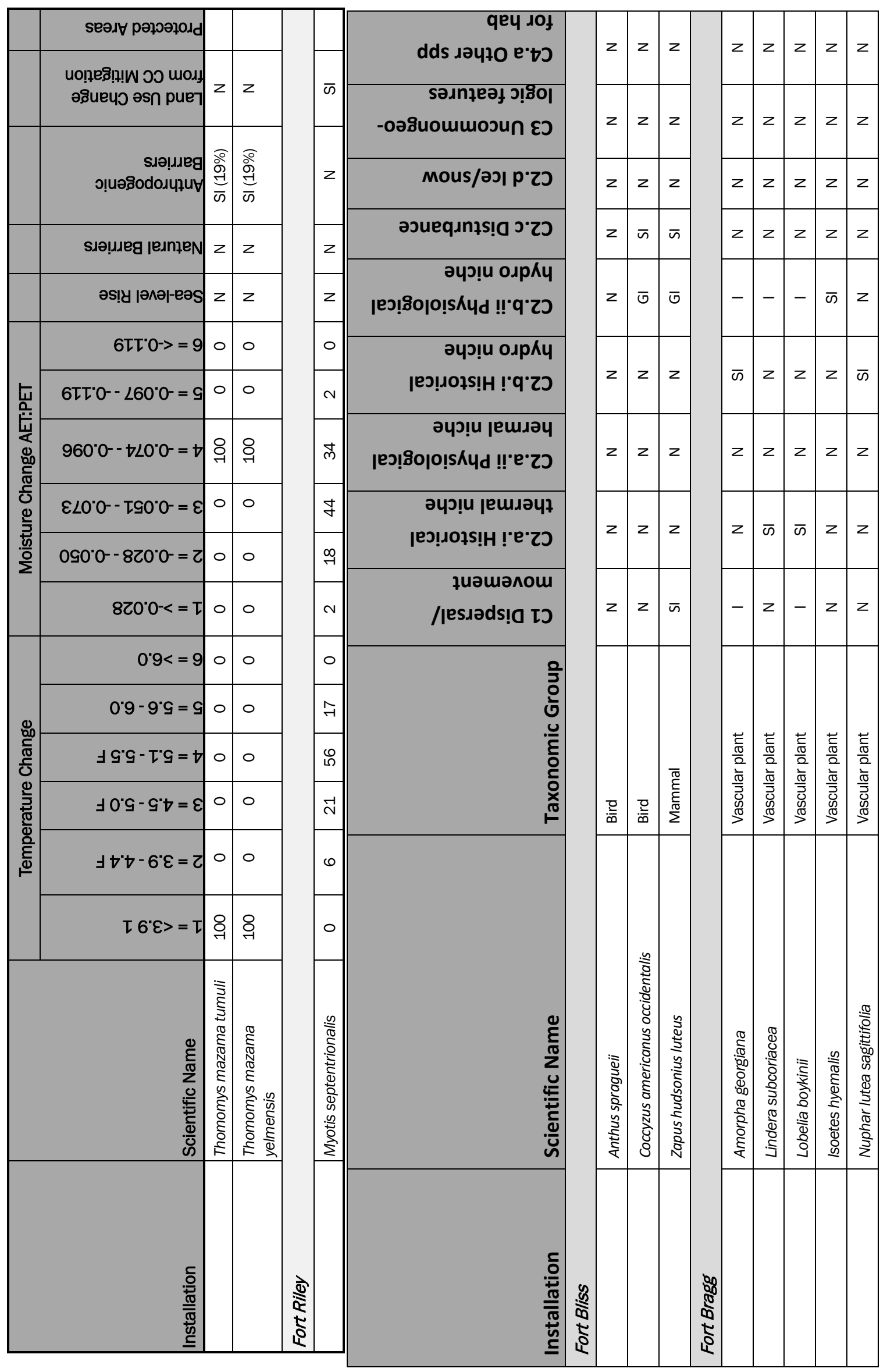




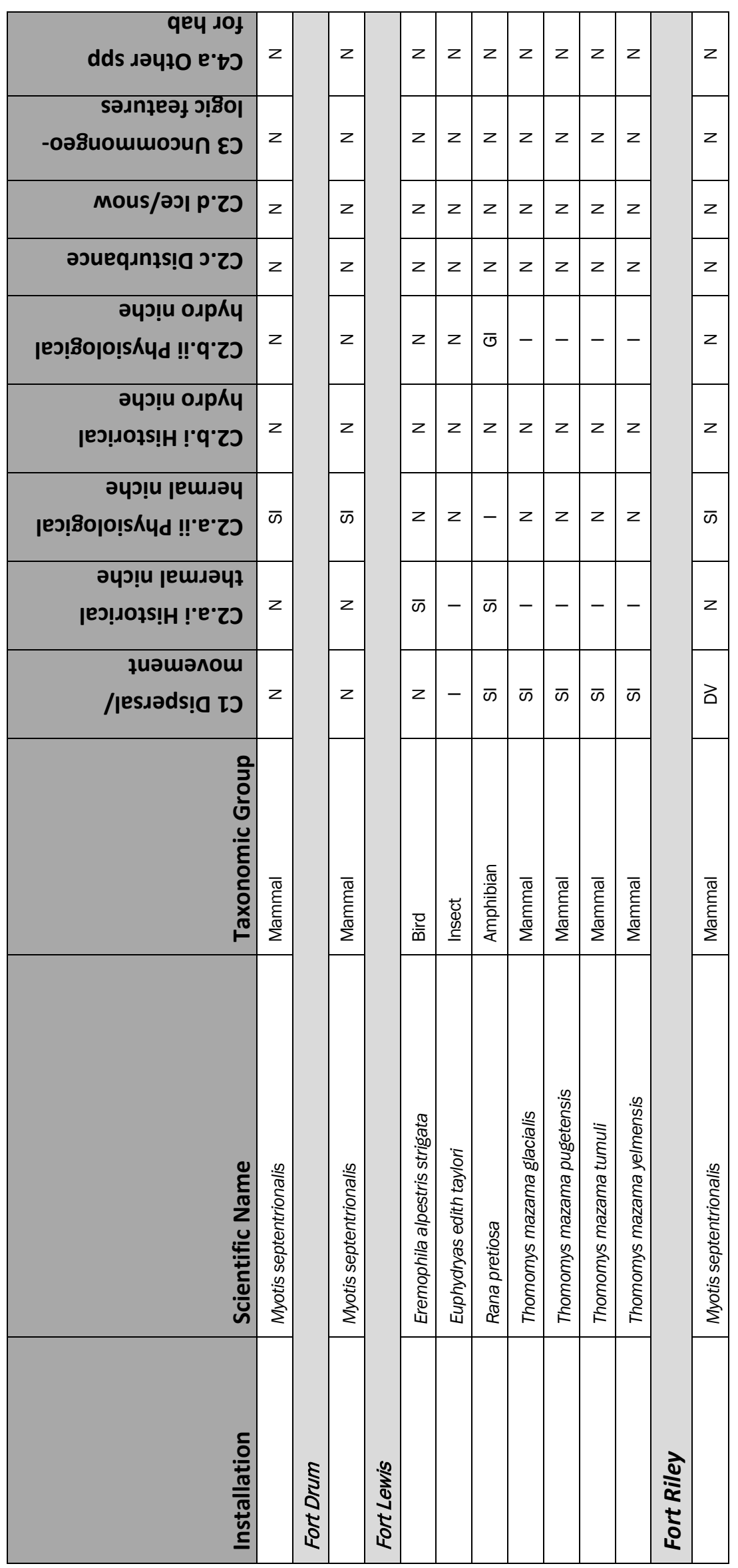




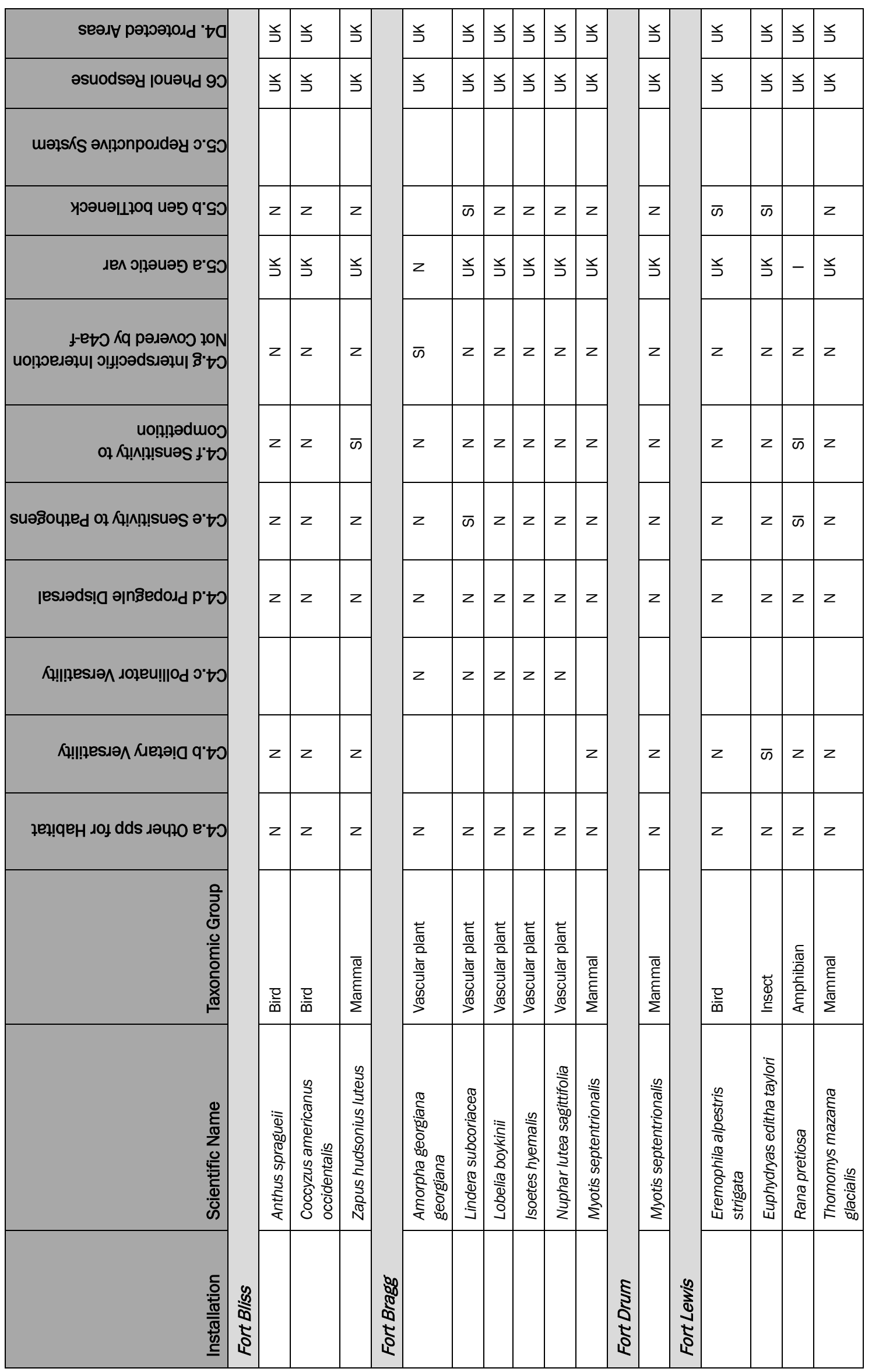




\begin{tabular}{|c|c|c|c|c|}
\hline 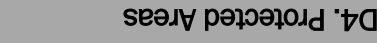 & 号 & 引 & 号 & 亏 \\
\hline әsuodsəy louəud 90 & Э & 卢 & 多 & Э \\
\hline 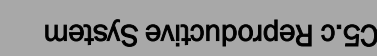 & & & & \\
\hline 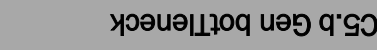 & $z$ & $z$ & $z$ & $z$ \\
\hline 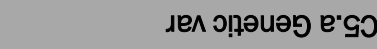 & 亭 & 卢 & Э & Э \\
\hline 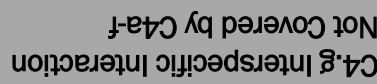 & z & $z$ & $z$ & $z$ \\
\hline 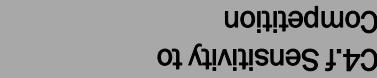 & $z$ & $z$ & z & $z$ \\
\hline 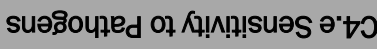 & $z$ & $z$ & $z$ & $z$ \\
\hline |esıəds! | ə|n乃ిedodd p'†O & $z$ & $z$ & $z$ & $z$ \\
\hline م & & & & \\
\hline 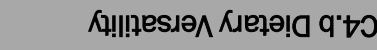 & $z$ & $z$ & $z$ & $z$ \\
\hline 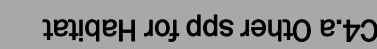 & z & z & $z$ & $z$ \\
\hline 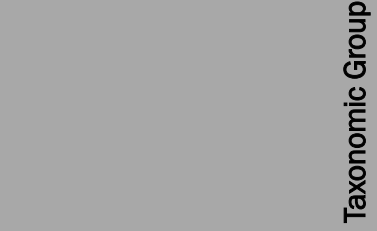 & 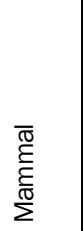 & 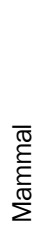 & 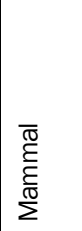 & $\begin{array}{l}\overline{\widetilde{\pi}} \\
\mathfrak{E}_{\bar{E}} \\
\sum^{\mathbb{\pi}}\end{array}$ \\
\hline 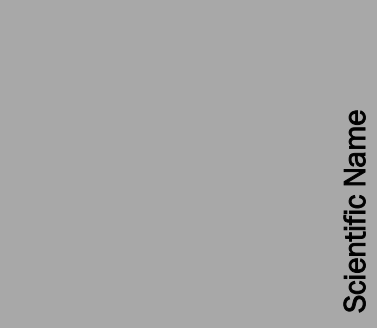 & 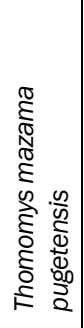 & 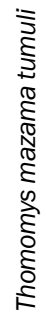 & 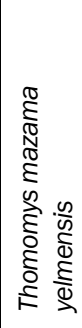 & 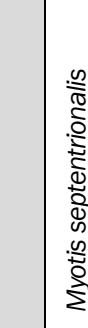 \\
\hline 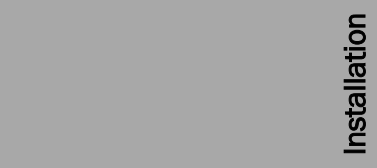 & & & & 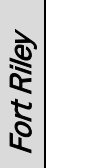 \\
\hline
\end{tabular}




\section{References and Bibliography}

\section{References}

Assistant Chief of Staff for Installation Management (ACSIM). 2010. Army Threatened and Endangered Species Report 2010. Washington, DC: ACSIM.

Atkins, K. E., and J . M. J . Travis. 2010. Local adaptation and the evolution of species' ranges under climate change. J ournal of Theoretical Biology 266:449-457.

Bagne, K. E., M. M. Friggens, and D. M. Finch. 2011. A System for Assessing Vulnerability of Species (SAVS) to Climate Change. General Technical Report RMRS-GTR-257. Fort Collins, CO: U.S. Department of Agriculture, Forest Service, Rocky Mountain Research Station.

Byers, E., and S. Norris. 2011. Climate Change Vulnerability Assessment of Species of Concern in West Virginia. Project Report. Elkins, WV: West Virginia Division of Natural Resources, http://wvdnr.gov/publications/PDFFiles/ClimateChangeVulnerability.pdf

Environmental Systems Research Institute, Inc. (ESRI). 2016. ArcGIS 10.2.2 (ESRI, Inc., Redlands, CA).

Homer, C. G., Dewitz, J. A., Yang, L., J in, S., Danielson, P., Xian, G., Coulston, J ., Herold, N. D., Wickham, J . D., and Megown, K. 2015. Completion of the 2011 National Land Cover Database for the conterminous United States-Representing a decade of land cover change information. Photogrammetric Engineering and Remote Sensing 81(5):345-354.

J ansson, R. 2003. Global patterns in endemism explained by past climatic change. Proceedings of the Royal Society of London B: Biological Sciences 270(1515):583-590.

NatureServe. 2011. Species at Risk on Department of Defense Lands: Updated Analysis, Report and Maps. DoD Legacy Project 10-247. Arlington, VA: NatureServe, http://www.denix.osd.mil/nr/upload/10-247-FS_SAR-on-DoD-Lands-Update.pdf

NatureServe. 2015. Natureserve Explorer: An Online Encyclopedia of Life. Web application. Version 7.1. Arlington, VA: NatureServe. Accessed 1 August 2015, http://explorer.natureserve.org

O’Neill, R. V., B. T. Milne, M. G. Turner, and R. H. Gardner. 1988. Resource utilization and landscape pattern. Landscape Ecology 2(1):63-69.

Reece, J . S., and R. F. Noss. 2014. Prioritizing species by conservation value and vulnerability: A new index applied to species threatened by sea-level rise and other risks in Florida. Natural Areas J ournal 34(1):31-45. doi: http://dx.doi.org/10.3375/043.034.0105 
Schiffers, K., E. C. Bourne, S. Lavergne, W. Thuiller, and J . M. J. Travis. 2012. Limited evolutionary rescue of locally adapted populations facing climate change. Philosophical Transactions of the Royal Society B: Biological Sciences 368(1610). doi:10.1098/rstb.2012.0083, http://rstb.royalsocietypublishing.org/content/368/1610/20120083

Schneider, S. H., S. Semenov, A. Patwardhan, I. Burton, C. H. D. Magadza, M. Oppenheimer, A. B. Pittock, A. Rahman, J . B. Smith, A. Suarez, and F. Yamin. 2007. Assessing key vulnerabilities and the risk from climate change. Climate Change 2007: Impacts, Adaptation and Vulnerability. M. L. Parry, O. F. Canziani, J . P. Palutikof, P. J . van der Linden, and C. E. Hanson, eds.. Contribution of Working Group II to the Fourth Assessment Report of the Intergovernmental Panel on Climate Change. Cambridge University Press, Cambridge, UK, pp 779-810.

Sperry, J . H., and T. J . Hayden. 2011. Use of a Climate Change Vulnerability Index for Assessing Species at Risk on Military Lands. ERDC/CERL TR-11-29. Champaign, IL: Engineer Research and Development Center, Construction Engineering Research Laboratory (ERDC-CERL), http://acwc.sdp.sirsi.net/client/search/asset/1006362

Sperry, J . H., W. A. Wall, and M. G. Hohmann. 2016. Evaluation of 757 Species Under U.S. Endangered Species Act Review on Department of Defense Lands and Their Potential Impact on Army Training. ERDC/ CERL TR-16-3. Champaign, IL: ERDC-CERL.

Stauffer, D. 1985. Introduction to Percolation Theory. London: Taylor and Francis.

Stein B. A., C. Scott, and N. Benton. 2008. Federal lands and endangered species: The role of military and other Federal lands in sustaining biodiversity. BioScience, 58(4)339- 347, http://www.nwf.org/ /media/PDFs/GlobalWarming/Reports/steinBioscience.pdf

Thieler, E. R., and E. S. Hammar-Klose. 2000. National assessment of coastal vulnerability to sea-level rise: Preliminary results for the U.S. Atlantic Coast. U.S. Geological Survey Open-File Report 99-593. Washington, DC: U.S. Geological Survey (USGS), http://pubs.usgs.gov/of/1999/of99-593/

Tuberville, T. D., K. M. Andrews, J . H. Sperry, and A. M. Grosse. 2015. Use of the NatureServe Climate Change Vulnerability Index as an assessment tool for reptiles and amphibians: Lessons learned. Environmental Management 56(4):822-834. doi:10.1007/s00267-015-0537-6.

U.S. Department of Defense (DoD). 2010. Quadrennial Defense Review. Washington, DC: DoD, http://www.defense.gov/Portals/1/features/defenseReviews/QDR/QDR_as_of_29JAN10_160 $\underline{0 . p d f}$

. 2011. U.S. Department of Defense (DoD) Instruction 4715.03. Subject: DoD Instruction. Washington, DC: Office of the Under Secretary of Defense, Acquisition, Technology and Logistics (OUSD[AT\&L]), http://www.dtic.mil/whs/directives/corres/pdf/471503p.pdf 2012. 2012 Climate Change Adaptation Roadmap. Washington, DC: DoD. 
2013. U.S. Department of Defense Manual. Subject: Integrated Natural Resources Management Plan (INRMP) Implementation Manual. DoDM 4715.03. Washington, DC: OUSD(AT\&L), http://www.dtic.mil/whs/directives/corres/pdf/471503m.pdf

. 2014a. 2014 Climate Change Adaptation Roadmap. Washington, DC: DoD, http://reliefweb.int/sites/reliefweb.int/files/resources/CCARprint.pdf

U.S. Environmental Protection Agency (USEPA). 2009. A Framework for Categorizing the Relative Vulnerability of Threatened and Endangered Species to Climate Change. EPA/ 600/R-09/011. Washington, DC: National Center for Environmental Assessment. Available from the National Technical Information Service, Springfield, VA, and online at http://www.epa.gov/ncea

U.S. Government Accountability Office (GAO). 2009. Climate Change Adaptation: Strategic Federal Planning Could Help Government Officials Make More Informed Decisions. GAO-10-113. Washington, DC: GAO.

U.S. Government Accountability Office (GAO). 2014. Climate Change Adaptation: DoD Can Improve Infrastructure Planning and Process to Better Account for Potential Impacts. GAO-14-446. Washington, DC: GAO, http://www.gao.gov/assets/670/663734.pdf

Urban, M. C. 2015. Accelerating extinction risk from climate change. Science 348(6234):571-573. doi:10.1126/science.aaa4984, http://science.sciencemag.org/content/348/6234/571.full

Wall, W. A., N. A. Douglas, Q. Y. J . Xiang, W. A. Hoffmann, T. R. Wentworth, and M. G. Hohmann. 2010. Evidence for range stasis during the latter Pleistocene for the Atlantic Coastal Plain endemic genus, Pyxidanthera Michaux. Molecular Ecology 19(19):4302-4314. doi:10.1111/j.1365-294X.2010.04793.x.

White House, The. 2009. Federal Leadership in Environmental, Energy and Economic Performance. Executive Order (EO) 13514. Washington, DC: The White House, Office of the Press Secretary, https://www.fedcenter.gov/programs/e013514/

White House, The. 2013. Preparing the United States for the Impacts of Climate Change. EO 13653. Washington, DC: The White House, Office of the Press Secretary, https://www.whitehouse.gov/the-press-office/2013/11/01/executive-order-preparing-unitedstates-impacts-climate-change

Wilhoit, J uliana M., Grace M. Díaz-Estrada, J ames P. Miller, and J ames Westervelt. 2017. Water Stress Projection Modeling. ERDC/ CERL TR-16-32. Champaign, IL: Engineer Research and Development Center, Construction Engineering Research Laboratory (ERDC-CERL).

Williams, S. E., L. P. Shoo, J . L. Isaac, A. A. Hoffmann, and G. Langham. 2008. Towards an integrated framework for assessing the vulnerability of species to climate change. Plos Biology 6:2621-2626.

With, K. A., and T. O. Crist. 1995. Critical thresholds in species' responses to landscape structure. Ecology 76(8):2446-2459, https://www.kstate.edu/withlab/publications/With\&Crist1995.pdf 
Young, B. E., E. Byers, G. Hammerson, A. Frances, L. Oliver, and A. Treher. 2015. Guidelines for Using the NatureServe Climate Change Vulnerability Index. Release 3.0, Arlington VA: NatureServe, http://www.natureserve.org/biodiversityscience/publications/guidelines-using-natureserve-climate-change-vulnerability-index-0

Young, B. E., N. S. Dubois, and E. L. Rowland. 2014. Using the Climate Change Vulnerability Index to inform adaptation planning: lessons, innovations, and next steps. Wildlife Society Bulletin doi:10.1002/ wsb.478, http://www.natureserve.org/biodiversity-science/publications/using-climate-changevulnerability-index-inform-adaptation

\section{Bibliography}

Anderson, H. E., and S. F. Pearson. 2015. Streaked Horned Lark Habitat Characteristics. Research Report. Olympia, WA: Washington Department of Fish and Wildlife, Wildlife Science Division.

Archie, K. M., L. Dilling, J. B. Milford, and F. C. Pampel. 2012. Climate change and western public lands: A survey of U.S. Federal land managers on the status of adaptation efforts. Ecology and Society 17(4):20, http://dx.doi.org/10.5751/ES$\underline{05187-170420}$

Bennett, N. L., P. M. Severns, C. Parmesan, and M. C. Singer. 2014. Geographic mosaics of phenology, host preference, adult size and microhabitat choice predict butterfly resilience to climate warming. Oikos 124(1):41-53.

Blaustein, A. R., S. C. Walls, B. A. Bancroft, J . J . Lawler, C. L. Searle, and S. S. Gervasi. 2010. Direct and indirect effects of climate change on amphibian populations. Diversity 2:281-313. doi:10.3390/d2020281.

Blouin, M. S., I. C. Phillipsen, and K. J. Monsen. 2010. Population structure and conservation genetics of the Oregon spotted frog, Rana pretiosa. Conservation Genetics 11(6):2179-2194. doi:10.1007/s10592-010-0104-x, http://link.springer.com/article/10.1007\%2Fs10592-010-0104-x

Bowerman, J ., and C. A. Pearl. 2010. Ability of Oregon spotted frog (Rana pretiosa) embryos from central Oregon to tolerate low temperatures. Northwestern Naturalist 91(2):198-202, http://www.jstor.org/stable/40856477?seq=1\#page_scan_tab_contents

Brunton, D. F., D. M. Britton, and W. C. Taylor. 1994. Isoetes hyemalis, sp. nov. (Isoetaceae): A new quillwort from the southeastern United States. Castanea 59(1):12-21.

Caplen, C. A., and C. R. Werth. 2000. Isozymes of the Isoetes riparia complex, I. Genetic variation and relatedness of diploid species. Systematic Botany 25(2):235-259.

Caldas, A. 2014. Species traits of relevance for climate vulnerability and the prediction of phonological responses to climate change. J ournal of the Lepidopterists' Society 68(3):197-202. 
Conlon, J . M., M. Mechkarska, E. Ahmed, L. Coquet, T. J ouenne, J . Leprince, H. Vaudry, M. P. Hayes, and G. Padgett-Flohr. 2011. Host defense peptides in skin secretions of the Oregon spotted frog Rana pretiosa: Implications for species resistance to chytridiomycosis. Developmental and Comparative Immunology 35(6):644-649. doi: 10.1016/j.dci.2011.01.017.

Davis, S. K. 2005. Nest-site selection patterns and the influence of vegetation on nest survival of mixed-grass prairie passerines. The Condor 107(3):605-616.

Davis, S. K., R. J . Fisher, S. L. Skinner, T. L. Shaffer, and R. M. Brigham. 2013. Songbird abundance in native and planted grassland varies with type and amount of grassland in the surrounding landscape. J ournal of Wildlife Management 77(5):908-919.

Dawson, T. P., S. T. J ackson, J . I. House, I. C. Prentice, and G. M. Mace. 2011. Beyond predictions: Biodiversity conservation in a changing climate. Science 332(6025):53-58. DOI: 10.1126/ science.1200303.

Diamond, S. E., A. M. Frame, R. A. Martin, and L. B. Buckley. 2011. Species' traits predict phonological response to climate change in butterflies. Ecology 92(5):1005-1012.

Dupont, Y. L., and M. Kato. 1999. Phenology and flower-visiting entomofauna of six species of Lindera (Lauraceae) in J apan. Nordic J ournal of Botany 19(6):707718. doi:10.1111/j.1756-1051.1999.tb00680.x.

Ehrlich, P. R., D. D. Murphy, M. C. Singer, C. B. Sherwood, R. R. White and I. L. Brown. 1980. Extinction, reduction, stability and increase: The responses of checkerspot butterfly (Euphydryas) populations to the California drought. Oecologia 46:101105.

Farrell, L. L. 2014. Examining the genetic distinctiveness of the western subspecies of Yellow-billed Cuckoo Coccyzus americanus occidentalis. Ardea 101(2):165-170.

Frey, J. K. 2015. Variation in phenology of hibernation and reproduction in the endangered New Mexico meadow jumping mouse (Zapus hudsonius luteus). PeerJ 3:e1138; DOI 10.7717/ peerj.1138

Frey, J . K., and J . L. Malaney. 2009. Decline of the meadow jumping mouse (Zapus hudsonius luteus) in two mountain ranges in New Mexico. The Southwestern Naturalist 54(1):31-44.

Frick, W. F., D. S. Reynolds, and T. H. Kunz. 2010. Influence of climate and reproductive timing on demography of little brown myotis Myotis lucifugus. J ournal of Animal Ecology 79(1):128-136.

Frick, W. F., P. M. Stepanian, J . F. Kelly, K. W. Howard, C. M. Kuster, T. H. Kunz, and P. B. Chilson. 2012. Climate and weather impact timing of emergence of bats. PLoS ONE 7(8):e42737. doi:10.1371/journal.pone.0042737.

Funk, W. C., C. A. Pearl, H. M. Draheim, M. J. Adams, T. D. Mullins, and S. M. Haig. 2008. Range-wide phylogeographic analysis of the spotted frog complex (Rana luteiventris and Rana pretiosa) in northwestern North America. Molecular Phylogenetics and Evolution 49(1):198-210. doi: 10.1016/j.ympev.2008.05.037. 
Government Accountability Office (GAO). 2009. Climate Change Adaptation: Strategic Federal Planning Could Help Government Officials Make More Informed Decisions. GAO-10-113. Washington, DC: GAO.

Hein, C. D. 2012. Potential Impacts of Shale Gas Development on Bat Populations in the Northeastern United States. An unpublished report submitted to the Delaware Riverkeeper Network, Bristol, Pennsylvania. Austin, TX: Bat Conservation International.

J ones, S. L. 2010. Sprague's Pipit (Anthus spragueii) Conservation Plan. Washington, DC: U.S. Department of Interior, Fish and Wildlife Service.

J ones, G. and H. Rebelo. 2013. Responses of bats to climate change: Learning from the past and predicting the future. in R. A. Adam, and S. C. Pedersen (eds). Bat Evolution, Ecology and Conservation. doi 10.1007/978-1-4614-7397-8_22. New York: Springer Science+Business Media.

Kalyn Bogard, H. J ., and S. K. Davis. 2014. Grassland songbirds exhibit variable responses to the proximity and density of natural gas wells. J ournal of Wildlife Management 78(3):471-482.

Kharouba, H. M., S. R. Paquette, J. T. Kerr, and M. Vellend. 2014. Predicting the sensitivity of butterfly phenology to temperature over the past century. Global Change Biology 20(2):504-514. doi:10.1111/ gcb.12429.

Li, Y., J . M. Cohen, and J . R. Rohr. 2013. Review and synthesis of the effects of climate change on amphibians. Integrative Zoology 8(2):145-161. doi:10.1111/17494877.12001.

Loeb, S. C., and E. A. Winters. 2013. Indiana bat summer maternity distribution: Effects of current and future climates. Ecology and Evolution 3(1)103-114. doi:10.1002/ ece3.440

Ludlow, S. M., R. M. Brigham, and S. K. Davis. 2015. Oil and natural gas development has mixed effects on the density and reproductive success of grassland songbirds. The Condor 117(1):64-75.

Lueders, A. S., P. L. Kennedy, and D. H. J ohnson, 2006. Influences of management regimes on breeding bird densities and habitat in mixed-grass prairie: An example from North Dakota. J ournal of Wildlife Management 70(2):600-606.

Luo, J ., K. Koselj, S. Zsebok, B. M. Siemers, and H. R. Goerlitz. 2014. Global warming alters sound transmission: Differential impact on the prey detection ability of echolocating bats. J ournal of the Royal Society Interface 11(91). doi:10.1098/rsif.2013.0961

Malaney, J . L., J . K. Frey, J . A. Cook. 2012. The biogeographic legacy of an imperiled taxon provides a foundation for assessing lineage diversification, demography and conservation genetics. Diversity and Distributions 18:689- 703.

McCaffery, R. M., and B. A. Maxell. 2010. Decreased winter severity increases viability of a montane frog population. Proceedings of the National Academy of Science 107(19):8644-8649. doi:10.1073/pnas.0912945107. 
McLaughlin, J . F., J . J . Hellmann, C. L. Boggs, and P. R. Ehrlich. 2002. The route to extinction: Population dynamics of a threatened butterfly. Oecologia 132:538548. Doi:10.1007/s00442-002-0997-2.

Muller, J . A. 2015. Landscape Scale Habitat Associations of Sprague's Pipit (Anthus Spragueii) Overwintering in the Southern United States. MS Thesis.

Pauli, B. P., P. A. Zollner, G. S. Haulton, G. Shao, and G. Shao. 2015. The simulated effects of timber harvest on suitable habitat for Indiana and northern long-eared bats. Ecosphere 6(4):58. http://dx.doi.org/10.1890/ES14-00336.1

Pearson, S. F., and B. Altman. 2005. Range-Wide Streaked Horned Lark (Eremophila alpestris strigata) Assessment and Preliminary Conservation Strategy. Olympia, WA: Washington Department of Fish and Wildlife, https://www.fws.gov/oregonfwo/species/data/streakedhornedlark/documents/shlassessment_strategy.pdf

Phillipsen, I. C., W. C. Funk, E. A. Hoffman, K. J . Monsen, and M. S. Blouin. 2011. Comparative analyses of effective population size within and among species: ranid frogs as a case study. Evolution 65(10):2927-2945. doi:10.1111/j.15585646.2011.01356.x.

Radchuk, V., C. Turlure, and N. Schtickzelle. 2013. Each life stage matters: The importance of assessing the response to climate change over the complete live cycle in butterflies. J ournal of Animal Ecology 82(1):275-285. doi:10.1111/j.13652656.2012.02029.x.

Rodgers, J . A. 2013. Effects of Shallow Gas Development on Relative Abundances of Grassland Songbirds in a Mixed-Grass Prairie. MS Thesis.

Royo, A. A., R. Bates, and E. P. Lacey. 2008. Demographic constraints in three populations of Lobelia boykinii: A rare wetland endemic. J ournal of the Torrey Botanical Society 135(2):189-199.

Ryan, M. E., W. J . Palen, M. J . Adams, and R. M. Rochefort. 2014. Amphibians in the climate vice: Loss and restoration of resilience of montane wetland ecosystems in the western US. Frontiers in Ecology and the Environment 12(4):232-240. doi:10.1890/130145, http://www.esa.org/esa/wp-content/uploads/2014/05/Ryan_Proof-3b.pdf

Singer, M. C., B. Wee, S. Hawkins, and M. Butcher. 2008. Rapid natural and anthropogenic diet evolution: Three examples from checkerspot butterflies. Specialization, Speciation, and Radiation: the Evolutionary Biology of Herbivorous Insects. Berkeley, CA: The University of California Press, pp 311-324.

Stinson, D. W. 2005. Draft Washington State Status Report for the Mazama Pocket Gopher, Streaked Horned Lark, and Taylor's Checkerspot. Olympia, WA: Washington Department of Fish and Wildlife.

Stinson, D. W. 2013. Draft Mazama Pocket Gopher Status Update and Washington State Recovery Plan. Olympia, WA: Washington Department of Fish and Wildlife. 
Straub, S. C. and J. J . Doyle. 2009. Conservation genetics of Amorpha georgiana (Fabaceae), an endangered legume of the Southeastern United States. Molecular Ecology 18(21):4349-4365.

Wall, W. A., M. G. Hohmann, A. S. Walker, and J . B. Gray. 2013. Sex ratios and population persistence in the rare shrub Lindera subcoriacea Wofford. Plant Ecology 214:1105-1114. doi:10.1007/ a11258-013-0234-6, http://link.springer.com/article/10.1007\%2Fs11258-013-0234-6\#/page-1

Wallace, C. S., M. L. Villarreal, and C. Riper, III. 2013. Influence of monsoon-related riparian phenology on yellow-billed cuckoo habitat selection in Arizona. J ournal of Biogeography 40(11):2094-2107.

Weiss, S. B., and A. D. Weiss. 1998. Landscape-level phenology of a threatened butterfly: A GIS-based modeling approach. Ecosystems 1(3):299-309, https://www.jstor.org/stable/3658765?seq=1\#page_scan_tab_contents

Wright, G. D., and J . K. Frey. 2014. Herbeal feeding behavior of the New Mexico meadow jumping mouse (Zapus hudsonius luteus). Western North American Naturalist 74(2):231-235.

Wright, G. D., and J. K. Frey. 2015. Habitat selection by the endangered New Mexico meadow jumping mouse on an irrigated floodplain. J ournal of Fish and Wildlife Management 6(1):112- 129; e1944-687X. doi: 10.3996/062014-J FWM-044. 


\section{Acronyms and Abbreviations}

\begin{tabular}{|c|c|}
\hline Term & Definition \\
\hline ACSIM & Assistant Chief of Staff for Installation Management \\
\hline AET & Actual Evapotranspiration \\
\hline ASA(ALT) & Assistant Secretary of the Army for Acquisition, Logistics, and Technology, \\
\hline BLM & Bureau of Land Management \\
\hline CCAR & Climate Change Adaptation Roadmap \\
\hline CCVI & Climate Change Vulnerability Index (CCVI) \\
\hline CEERD & US Army Corps of Engineers, Engineer Research and Development Center \\
\hline CERL & Construction Engineering Research Laboratory \\
\hline CONUS & Continental United States \\
\hline DoD & U.S. Department of Defense \\
\hline DoDI & Department of Defense Instruction \\
\hline DoDM & Department of Defense Manual \\
\hline ECOS & Environmental Conservation Online System \\
\hline EO & Executive Order \\
\hline ERDC & U.S. Army Engineer Research and Development Center \\
\hline ERDC-CERL & $\begin{array}{l}\text { Engineer Research and Development Center, Construction Engineering } \\
\text { Research Laboratory }\end{array}$ \\
\hline ESA & U.S. Endangered Species Act \\
\hline ESRI & Environmental Systems Research Institute, Inc. \\
\hline EV & Extremely Vulnerable \\
\hline GAO & Government Accountability Office \\
\hline GIS & Geographic Information System \\
\hline HV & Highly Vulnerable \\
\hline IE & Insufficient Evidence \\
\hline INRMP & Integrated Natural Resources Management Plans \\
\hline JBLM & Joint Base Lewis-McChord \\
\hline LV & Less Vulnerable \\
\hline MV & Moderately Vulnerable \\
\hline NS CCVI & NatureServe Climate Change Vulnerability Index \\
\hline OACSIM & Office of the Assistant Chief of Staff for Installation Management \\
\hline PET & Percent Evapotranspiration \\
\hline RMRS-GTR & Rocky Mountain Research Station General Technical Report \\
\hline SAVS & System for Assessing Vulnerability of Species \\
\hline SF & Standard Form \\
\hline TR & Technical Report \\
\hline USFWS & U.S. Fish and Wildlife Service \\
\hline USEPA & U.S. Environmental Protection Agency \\
\hline USGS & U.S. Geological Survey \\
\hline
\end{tabular}




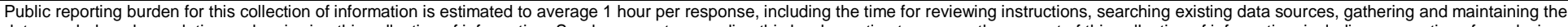

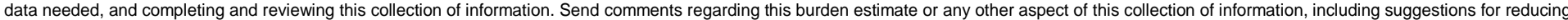

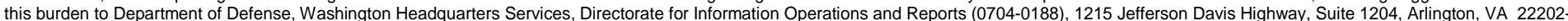

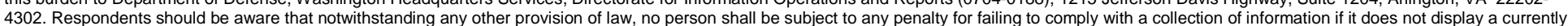
valid OMB control number. PLEASE DO NOT RETURN YOUR FORM TO THE ABOVE ADDRESS.

\begin{tabular}{l|l} 
valid OMB control number. PLEASE DO NOT RETURN YOUR FORM TO THE ABOVE ADDRESS. \\
\hline 1. REPORT DATE (DD-MM-YYYY)
\end{tabular}
1. REPORT DATE(DD-MIMYY
2. REPORT TYPE
Final

\section{TITLE AND SUBTITLE}

Multiscale Assessment of Listed and At-Risk Species' Climate Change Vulnerabilities

3. DATES COVERED (From - To)

\section{5a. CONTRACT NUMBER}

\section{5b. GRANT NUMBER}

\section{5c. PROGRAM ELEMENT}

\section{AUTHOR(S)}

Matthew G. Hohmann and Wade A. Wall

\section{5d. PROJECT NUMBER}

622720A896

5e. TASK NUMBER

5f. WORK UNIT NUMBER

F94KF0

7. PERFORMING ORGANIZATION NAME(S) AND ADDRESS(ES)

U.S. Army Engineer Research and Development Center (ERDC)

Construction Engineering Research Laboratory (CERL)

PO Box 9005,

Champaign, IL 61826-9005

\section{PERFORMING ORGANIZATION REPORT} NUMBER

ERDC/ CERL TR-17-21

\section{SPONSORING I MONITORING AGENCY NAME(S) AND ADDRESS(ES)}

Office of the Assistant Chief of Staff for Installation Management

600 Army Pentagon

Washington, DC 20310

10. SPONSOR/MONITOR'S ACRONYM(S)

OACSIM-ISE

11. SPONSOR/MONITOR'S REPORT NUMBER(S)

\section{DISTRIBUTION I AVAILABILITY STATEMENT}

Approved for public release; distribution is unlimited.

\section{SUPPLEMENTARY NOTES}

\section{ABSTRACT}

Climate change is of concern to the U.S. Department of Defense because climate change-driven increases in the number of species Federally listed under the U.S. Endangered Species Act (ESA) and stress to listed species can lead to additional requirements and potential restrictions on training land use. A first step in guiding management strategies to promote climate change adaptation is to assess species' vulnerabilities. However, vulnerability assessments conducted at a single scale or for arbitrary regions offer limited information to guide management decisions. This work developed and demonstrated an approach for multiscale species vulnerability assessments that integrates weighted estimates of range-wide and local vulnerability, and vulnerability on Federal land, where species' occurrence often influences ESA listing decisions. The approach was applied to 16 plant and animal species on five regionally representative Army installations. The assessments were used to rank species based on their occurrence on multiple installations across the Army and to rank the five study installations based on aggregate species' vulnerabilities. This approach is suitable for integrating climate change considerations into installation Integrated Natural Resource Management Plans, for evaluating whether climate changedriven impacts to listed species will affect installation resilience, and for identifying potential conservation partners among Federal land managers.

\section{SUBJECT TERMS}

Endangered species--United States, Military bases, Climatic changes, Multiscale modeling, Environmental management

\section{SECURITY CLASSIFICATION OF:}

\section{a. REPORT}

Unclassified

\section{b. ABSTRACT}

Unclassified

\section{LIMITATION OF ABSTRACT}

\section{c. THIS PAGE}

Unclassified

\section{NUMBER} OF PAGES

56 19a. NAME OF RESPONSIBLE PERSON

19b. TELEPHONE NUMBER (include area code) 